\title{
Dua Imperialis dalam Perkembangan Dasar Perdagangan Bebas dan Pelabuhan Bebas Di Negeri-Negeri Selat, 1786-1826
}

\author{
Oleh \\ Sivachandralingam Sundara Raja
}

Kepesatan perdagangan England dengan negeri China mendesak Syarikat Hindia Timur Inggeris mencari sebuah pelabuhan persinggahan di sekitar Kepulauan Melayu untuk memudahkan kapal-kapalnya berlabuh, memperlengkap, mengisi dan menunggu tiupan angin monsun yang sesuai untuk membawa mereka ke negeri China atau balik ke India. ${ }^{1}$ Keperluan untuk menguasai sebuah pelabuhan juga menjadi amat perlu kerana jalan-jalan perdagangan biasa yang melalui Selat Melaka dikuasai oleh Belanda di Melaka dan kedudukan Bangkahulu pula terlalu jauh dan menyusahkan. Selat Sunda yang merupakan satu lagi jalan penting pula dikawal oleh Belanda di Betawi. Penguasaan sebuah pelabuhan di Selat Melaka juga dipercayai dapat menjamin

Artikel ini adalah pengubahsuaian dari bab kelima tesis M.A. penulis yang berjudul "Idea Perdagangan Bebas di England dan Pengaruhnya Ke Atas Dasar Perdagangan Bebas dan Pelabuhan Bebas Di Negeri-Negeri Selat, 1786-1826".

1. P.P. Courtenay, A Geography of Trade and Development in Malaya, London, G.Bells and Sons Ltd., 1972, hlm. 64. 
perdagangan dan melindungi perdagangan negeri China. la juga akan dapat berperanan sebagai pusat pengumpulan barangan Kepulauan Melayu untuk dihantar ke negeri China dan sebagai pangkalan tentera untuk menentang pengaruh Belanda atau Perancis. ${ }^{2}$

Berasaskan senario inilah usaha-usaha yang rancak dijalankan untuk mencari penempatan-penempatan baru di Kepulauan Melayu. Penguasaan Pulau Pinang dan Singapura sesungguhnya menjawab kehendak ini. Penguasaan Negeri-negeri Selat dan lebih-lebih lagi dengan menjadikannya pelabuhan bebas pada awal abad ke-19 telah memungkinkan England menerokai pasaran-pasaran kaya di Timur dan membina satu bentuk empayar ekonomi baru. ${ }^{3}$ Pelabuhanpelabuhan bebas ini juga secara tidak langsung telah mengintegrasikan Semenanjung Tanah Melayu dan Kepulauan Melayu dalam lingkungan ekonomi England.4

2. N. Tarling. Britich Policy in the Malay Peninswla and Archipelago, 18241871, Singapore. Oxford University Press, 1975, hlm. 12; E. Trapaud, A Short Accownt of the Prince of Hials Lsland, Singapore, Eastern University Press, 1962, hlm. 17-20.

3. J.B. Williams, Britist Commercial Ablicy and Great Britian's Thade Bnpansion It5t 1850, London, Oxford University Press, 1973, hlm. 78.

4. Courtenay, A Geagraphy of Trade, hlm. 60 . 
Individu-individu seperti Francis Light dan Stamford Raffles telah terlibat dalam mengembangkan dasar perdagangan bebas ${ }^{5}$ dan pelabuhan bebas ${ }^{6} \mathrm{di}$ Negeri-negeri Selat. Francis Light telah memainkan peranan penting dalam penguasaan Pulau Pinang dan perkembangannya sebagai pelabuhan bebas di

5. Free Trade atau dasar perdagangan bebas adalah suatu syarat perdagangan antarabangsa di mana sesebuah negara tidak mengenakan duti kastam atau duti-duti lain ke atas import barangan dari negara lain. Teori perdagangan antarabangsa ini menunjukkan bahawa perdagangan bagi dunia secara keseluruhan akan membawa faedah jika ia tidak tertakluk kepada sekatan seperti tarif, kuota dan sebagainya. Tidak pernah ada waktu-waktu tertentu di mana perdagangan antara negara bebas secara keseluruhan (J.L. Hanson, A Dictionany of Economic and Commerce, Plymouth, Macdonald and Evans Ltd. 1984, hlm 214). Cook menakrifkan perdagangan bebas sebagai "Free exchange of commodities, unrestricted by the imposition of duties by government, except perhaps for revenue purposes" (C. Cook, Dictionary of Historical Terms, A Guide to Names and Events of over 1,000 years of World History 1714 -1980, New York, Longman Inc., 1983, hlm. 123). Encyclopaedia Britannica pula menakrifkan Free Trade sebagai “... a policy by which a government does not discriminate against imports in favour of national products or interfere with exports in order to favour consumers in the home market. Free trade does not mean that a government abandons all control and taxation of imports and exports but only that this control and taxation are not used to protect the home producer against the foreign consumer" (Encyclopedia Britiannica, Vol. 9. Chicago, William Benton, 1970, hlm. 850-851). Dalam kes Negeri-negeri Selat, ia dapat diperhatikan dari segi perdagangan yang berkembang pesat atas inisiatif individu pedagang dan pengusaha. Kerajaan tidak menggalakkan ataupun campur tangan dalam aktiviti-aktiviti perdagangan kecuali menyediakan kemudahan-kemudahan pentadbiran yang cekap dan matawang yang stabil. Dalam keadaan begini, individu pedagang bebas menjalankan perdagangan dan kumpulan-kumpulan dan komuniti-komuniti yang berlainan mengkhususkan perdagangan dalam bidang yang mereka lebih cekap melalui pendekatan mereka sendiri (D.J.M. Tate, The Making of Modern Sowth-East Asia, Economic and Social Change, Vol. 2, Kuala Lumpur, Oxford University Press, 1979, hlm. 157).

6. Free Port atau pelabuhan bebas membawa pengertian sesebuah pelabuhan yang terbuka kepada pedagang-pedagang asing dan tempatan serta barangan yang dibawa masuk bebas tanpa dikenakan cukai. Encylopaedia Britannica mentakrifkan Free Port sebagai, "A free port or free zone within a port is an area within which goods may be landed, handled, manufactured and reshipped without the intervention of the customs authorities. The defined area is subject to all the usual tal service but is entirely exempt conditions, inspection of vessels, immigration and postal salam kes Negeri-negeri Selat, from customs" (Encylopaedia Britannica, hiukan sebagai pelabuhan bebas, pemerintah sewaktu Pulau Pinang dan Singapura dimajuka sebah. komisyen dan perkongsian dalam tempatan tetap mengutip cukai melalui sistem hadiah. komisyen dan perkongson dalom 
akhir abad ke-18. ${ }^{7}$ Stamford Raffles pula bertanggung jawab dalam perkembangan Singapura sebagai pelabuhan bebas pada awal abad ke-19.

perdagangan di pelabuhan mereka (Tate, The Making of Modem South-East Asia, hilm. 150; G. Tregonning, "Penang and The China Trade", MIH, Vol. 6, No. 1. 1959, hlm. 59). Perkara ini juga disebut dalam rekod Negeri-negeri Selat. "... to the invariable practise to all Malay Ports, have been in the habit of receiving antar-antaran, or complimentary presents from the Nakhodahs of Junks and Native vessels..." (Straits Settlement Records, Singapore National Library, selanjutnya SSR (SNL), Vol. 10, ff. 337-338).

7. Pulau Pinang dikuasai secara rasmi pada 11 Ogos, 1786. Antara tahun 1786-1805, Pulau Pinang tertakluk di bawah pentadbiran kerajaan Bengal di India (L.A. Mills, "British Malaya 1824-1967", JMBRAS, Vol. 33, Pt. 3, 1960, him. 38-41). Antara tahun'1805-826. tarafnya dinaikkan ke kedudukan Presidensi ke-4, setaraf dengan Bengal, Madras dan Bombay di bawah kekuasaan Gabenor Bengal (R.O. Winstedt, "A History of Malaya", JMBRAS, Vol. 3, Pt. 1, 1935, hlm. 38-41). Pada tahun 1826, Pulau Pinang, Melaka dan Singapura disatukan menjadi Presidensi India dengan Pulau Pinang menjadi pusat pentadbiran. Pada tahun 1830, taraf Presidensi dimansuhkan dan ketiga-tiga penempatan ini menjadi Residensi di bawah arahan Gabenor dan Konsul di Bengal. Hanya pada tahun 1832, ibu pejabatnya dipindahkan dari Pulau Pinang ke Singapura (Winstedt, "A History of Malaya" p. 203). Pulau Pinang dimajukan sebagai pelabuhan bebas sejak penguasaannya secara rasmi pada 11 Ogos, 1786. Ia hanya mendapat status sebagai pelabuhan bebas secara rasmi pada 22 Januari, 1787 ("Notices of Pinang". Jowmal of Indian Archipelago and Eastem Asia, (selanjutnya JIA,) Vol. 4, 1850, hlm. 633). Status ini berkekalan sehingga tahun 1800 . Cukai import sebanyak $2 \%$ dikenakan ke atas bijh timah, lada hitam dan pinang pada tahun 1801 bila George Leith menjadi Leftenan Gabenor pada tahun 1800 (Straits Settlements Records (Indian Office Library), selanjutnya SSR (IOL), Vol. 1, f. 30). Pada tahun 1802, duti ini dimansuhkan dan sebagai ganti dikenakan duti eksport ke atas lada hitam dan barangan lain (H.P Clodd, Malaya's First British Pioneer, The Life of Francis Light, London, Bruces Gawthorn Ltd., 1948, hlm. 140). Pada tahun 1826, Pulau Pinang mendapat semula statusnya sebagai pelabuhan bebas.

8. Singapura dikuasai secara rasmi oleh British pada 6 Februari, 1819 dan ia terletak di bawah pentadbiran Presidensi Bangkahulu di Sumatera (C.B. Buckley, An Anectdotal History of Old Times in Singapore, Singapore, Oxford University Press, 1984, him. 49). Pada tahun 1826. Pulau Pinang. Singapura dan Melaka disatukan sebagai Presidensi dengan Pulau Pinang sebagai pusat pentadbiran. Singapura dijadikan pelabuhan bebas pada 6 Februari, 1819 (Clodd, Malaya's First British Pioneer, hlm. 67). Pengisytharan secara rasmi hanya dibuat pada $1 \mathrm{hb}$. Januari, 1823 (C.E. Wurtzburg. Raftles of The Ecostem Isles, London, Hodder and Stoughton, 1954, hlm. 616-617). Pada 21 November. 1826. Pulau Pinang dan Melaka turut sama diisytiharkan sebagai pelabuhan bebas(Wons Lin Ken. "The Trade of Singapore 1819-2969", JMBRAS, Vol 33, Pt. 4, 1960, him. 180). 
Dalam konteks ini perlulah diperincikan faktor-faku,r yang mendor's,ng kedua dua tokoh ini mempeloprori dasar perdagangan bebas di Kepulacian Mrlayu.

\section{PERANAN FRANCIS LGHT}

\section{CITA-CITA FRANCIS LIIHT}

Cita-cita Francis Light' untuk menguasaj kekayaan Kepulauan Melayu menjadi salah satu faktor penting Yulau Yinang dimajukan stbagaj stbuah pelabuhan bebas. Dengan menjardikan Yulau Pinang sebuah pelabuhan betbas, sebahagian besar daripada kekayaan perdagangannya dibrolot oleh $\mathrm{Francis}$ light dan rakannya James Scott." Kedua-duanya menyertai perkongsian perdagangan (joint stock) pada tahun 1787 dan salah satu syarat perkongsian tersebut ialah Francis Light harus memberi kebebasan kepada mereka yang mengunjungi

9. Francis Light dilahirkan di Suffolk England pada tahun 1745 dan beliau ke Timur dalam usia yang muda sewaktu berkhidmat dalam tentera marin Syarikat Hindıa Timur Ingeris (A.M. Skinner "Memoir of Captain Francis Light", JSBRAS, Vol. 25. 1595. hlm. 1). Francis Light memulakan kerjayanya sebagai pe-gawai muda laut. country-rrader. Denyeludup senjata api dan pedagang persendirian. Kemuncak kerjayanya ialah apabila dilantik menjadi Penguasa Prince of Wales Island pada tahun 17\%6 francis Iaght meninggal dunia pada 21 Disember, 1794 (K. Bonnty. "Francis Light and Penang". JMBRAS, Vol. 38, Pt. 1, 1965, him. 135).

10. James Scott adalah seorang pedagang bangsa Scot yang mempunyai pengalaman berdagang selama 22 tahun di Kepulauan Melayu. Antara tahun 1761-1763 beliau menjadi teman sekapal Francis light. James Scott ke Timur sebayai pelayar dalam kapal yang diupah oleh Syarikat Hindia Timur Inggeris. Di Junk Ceylon (Ljung Salankj James Scott dan Francis Light mendirikan pusat perdagangan dan pada tahun 1787 menyrrtai Derkongsian untuk menjalankan perdagangan di Pulau Pinang. Pada tahap awal Derdagangan Pulau Yinang dikuasai oleh syarikst Scott. Lintuk keterankan lanjut tentanq

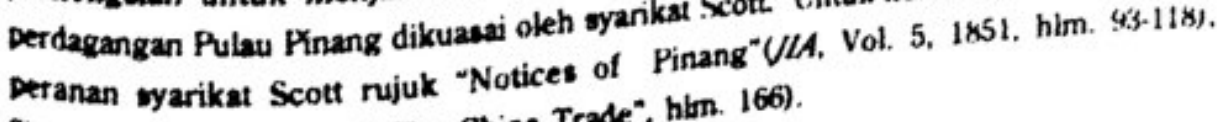
Trogonning. "Penang and The China Trade", hibn. 166). 
pelabuhan, tetapi tidak boleh campurtangan dalam hal pengurusannya." Syarat ini menjamin James Scott kedudukan yang dominan dalam perdagangan Negerinegeri Selat. ${ }^{12}$

Kepentingan perdagangan Francis Light dan James Scott, disuarakan dengan menarik oleh juruukur tanah Pulau Pinang, Kapten Kyd pada tahun 1795. Menurutnya:

... Light Scott combination had been so great a bar to all free enterprise that no commercial howse or merchant of any credit had ever attempted to form an establishment. ${ }^{13}$

Ternyata Francis Light sedar akan faedah yang bakal diperolehi oleh Pulau Pinang sebagai penempatan perdagangan. Keinginannya untuk memajukan perdagangan, bukan bertujuan untuk melihat perluasan perdagangan Syarikat

11. Perkongsian perdagangan antara James Scott dan Francis Light dijalankan mengikut empat ketetapan/resolusi. Antaranya:

(a) Francis Light akan memberi kebebasan penuh dalam kegiatan perdagangan kepada pedagang yang mengunjungi pelabuhan tetapi tidak akan campurtangan dalam rengurusannya.

(b) Membeli dan menjual untuk keuntungan jangka pendek Pulau Pinang.

(c) Untuk membeli hasil-hasil dari negeri-negeri sekitar dengan harga yang paling tinggi dan sebagai ganti (in return) menjual barangan India dan China dengan harga yang rendah tetapi dengan jaminan untung.

(d) Untuk menetapkan pada awal tahun harga barangan yang akan di jual dan di beli di pulau berkenaan (Lebih lanjut "Notices of Pinang", JIA, Vol. 5, 1851, hlm. 100101).

12. Melalui perkongsian perdagangan antara Francis Light dan James Scott, $90 \%$ perdagangan Pulau Pinang dikatakan melalui syarikat James Scott dan Francis Light (Courtenay, A Geography of Thade... hlm. 17).

13. Kyd kepada Bengal, 2 Ogos, 1795, SS(F)R, Vol. 7, memetik dari Tregonning, th Bnitish in Malayes. The Finst Fonty Yoars, 1786-1826, hlm. 166. 
Hindia Timur Inggeris semata-mata, tetapi didorong oleh kepentingan peribadi. ${ }^{14}$ Hal ini tidaklah menghairankan kerana gaji yang diterima oleh beliau amatlah sedikit. Malah beliau sendiri mengakui yang beliau mungkin telah lama meninggalkan jawatan tersebut jika bukan kerana perkongsian perdagangan dengan James Scott. ${ }^{15}$

Francis Light dan rakannya James Scott juga berjaya meraih kekayaan melalui sistem tanah yang diperkenalkan ketika Pulau Pinang mula dikuasai. ${ }^{16}$ Melalui dasar ini Francis Light telah menggalakkan pembukaan tanah dan memberikan geran (title) kepada mereka yang mengusahakannya. Sistem ini telah membawa kepada penguasaan berpuluh-puluh ekar tanah oleh orang perseorangan dan bangsa Eropah yang lain. Langkah Francis Light berbuat

14. "This desire (pengambilan Pulau Pinang) does not seem to have been motivated by his interest to see an expansion in the Company's trade but rather, it seems to have been a purely personal interest. Light stood to profit tremendously by the establishment of a British settlement which would give him all the security and protection needed for an extension of his commercial interests, and it was towards the achievement of this end that we must view the efforts and resourcefulness of Francis Light" (R. Bonney, "Francis Light, The Nonya and Penang", Jowmal of the Historical Society, 1964/65, hlm. 34).

15. "My expenses exceeding salary just as 2 to 1 ... I should long ago have been obliged to leave Superintendency, had I not engaged in partnership with James Scott, a most expert merchant" (KJ. Fielding (ed). "The Settlement of Penang by James Scott", JMBRAS, Vol. 28, Pt. 1, 1955, hlm. 38). Hal ini juga dinyatakan dalam Memoirnya, "In 1790 Light began to find that the duties of Superintendent of the growing settlement were incompatible with his position as a merchant, while the small salary (RS, 1,000 per month) which he received from Government was insufficient to warrant his giving up trade...His combined position of Superintendent and principal merchant in Penang gave him abundant opportunity of enriching himself, and in those lax days with examples like VANISITTART and MACPHERSON before him, such scruples must have seemed to many almost Quixotic" (A.M. Skinner, "Memoir of Captain Francis Light", JSBRAS, Vol. 28, Pt. 2, 1895, him. 7). Rujuk juga (SSR(IOL). Vol 1, f. 15; Vol. 7, ff. 168-169).

16. Siveaporr Free Press \& Mercantile Adoerticer, selanjutnya SFPMA, 21 September. 1843. 
demikian adalah untuk memasyhurkan penempatannya dan menggalakkan imigrasi.: Satu perkara yang menarik dalam kes ini ialah tindakannya menyerahkan tanah secara bebas itu tidak disenangi oleh kerajaan India, tetapi Light tidak mengendahkannya. ${ }^{18}$

Tanah yang diberikan ini akhirnya terpaksa ditinggalkan apabila pemilik tanah yang rata-rata terdiri daripada bangsa Eropah dan Asia tidak tinggal secara tetap sebagai penduduk Pulau Pinang. Tambahan pula Pulau Pinang tidak bersih, tidak mempunyai pegawai perubatan dan kemudahan perubatan. Keadaan ini mengakibatkan kadar kematian di kalangan semua bangsa amat tinggi. Ini menyebabkan ramai pemilik tanah mula meninggalkan penempatan mereka dan kebanyakan tanah berharga mula jatuh ke tangan mereka yang dapat menawarkan harga yang rendah. Kesempatan ini digunakan oleh firma Scott untuk membeli kesemua tanah tersebut. ${ }^{19}$ Syarikat Scott juga berperanan sebagai bankers dan peminjam wang kepada penduduk Pulau Pinang. Syarikat Scott juga menawarkan bantuan kewangan dengan menerima cagaran. Dengan cara ini syarikat Scott berjaya mengumpul satu juta rupee pada tahun 1796. Keuntungan yang diperolehi oleh syarikat Scott telah memungkinkan kerajaan Pulau Pinang mengaut keuntungan yang besar melalui percukaian. ${ }^{20}$

17. “... Mr. Light encouraged the formation of a permanent population in Penang by offering land unconditionally to all who would take posession of it. This gave great impetus to immigration and the impostion of restraints to which the settlers were unused would perhaps have been injudicious at that early period" (SFPMA, 28 September, 1843). Rujuk juga (SSR (IOL), Vol. 7, ff. 231-232).

18. "In August 1794 the Supreme Government resolved that no allotment of lands should be made in perpetuity or upon lease exceeding five years! Mr. Light considering that such a rule would put to an end to the improvement of the island, never promut gated nor acted upon it" (SFPMA, 21 September, 1843).

19. F.G. Stevens, "A Contribution to the Early History of Prince of Wales Island", JMBRAS, Vol . 7, Pt. 3, 1929, hlm. 380-381.

20. The house of Messrs Scott and Company became the purchasers, and gave the ven wnexpected and lange sum of 12,360 dollars for the duties; but as I have since learnt, they were determined at all events to become the purchasers in order to obtain an infivence in the trade, no just conclusion as to the real value of the duties can be formed from the present very high prices" ("Notices of Pinang", JLA, Vol. 5, 1851. hlm. 171). 
Hakikat bahawa cita-cita Francis Light menjadi faktor utama penguasaan Pulau Pinang menjadi lebih nyata apabila ditinjau pengetahuan yang ada pada dirinya tentang hal-ehwal dan kedudukan negeri-negeri Melayu. Melalui surat yang dikirimkan oleh Francis Light kepada Gabenor Jeneral India, Lord Cornwallis, yang bertarikh 7 Januari, 1789, beliau telah memberi gambaran lengkap tentang negeri-negeri Melayu yang terletak di sekitar Pulau Pinang dan hasil bumi yang disumbangkan oleh negeri-negeri ini. ${ }^{21}$ Sudah tentu maklumat ini telah diperolehi oleh beliau sebelum menguasai Pulau Pinang. Hal ini tidaklah menghairankan, kerana selaku country trader beliau telah menjalinkan hubungan yang erat dengan pemerintah Negeri-negeri Melayu. Justeru itu beliau sedar jika Pulau Pinang dijadikan pelabuhan bebas, pasti akan memudahkan pengumpulan kekayaan dari kawasan-kawasan sekitarnya. ${ }^{22}$

Hakikat kepentingan peribadi Francis Light mendahului faktor-faktor lain juga jelas kelihatan daripada tindakannya menguasai Pulau Pinang tanpa memaklumkan kehendak bantuan ketenteraan oleh Sultan Kedah, Raja Abdullah Mahrum Shah (1779-1802) kepada Gabenor Jeneral di India. ${ }^{23}$ Keputusan Sultan Abdullah untuk memajakkan Pulau Pinang kepada Syarikat Hindia Timur Inggeris sebahagian besarnya adalah didorong oleh kebimbangan baginda

21. Lebih lanjut tentang maklumat yang diperolehi oleh Francis Light tentang Ava, Ujung Salang, Kedah, Perak, Selangor,, Rembau, Padang dan Trengganu rujuk (Singapore Chronicle\& Commercial Register, selanjutnya SCCR, 1 Janurani, 1835; The New Atlas and The Commercial Gazeteer, 1917, hlm. 3).

22. Francis Light juga telah meramalkan bahawa setelah Pulau Pinang dibuka, ia akan berjaya menarik pedagang dari Melaka, pantai Coromandel dan kawasan-kawasan lain. Ujung Salang diramalkan dapat menyumbangkan bijih timah berjumlah 500 tan setiap tahun (SSR(IOL), Vol. 3, f.52). Menurutnya adalah wajar penduduk yang bakal datang ke Pulau Pinang di beri galakan kemudahan tanah dan diadakan pasukan polis untuk menjamin keselamatan (East India Company Reconds Relating to The Straits Settlements, selanjutnya EICRRTSS, Vol, 1, f. 3).

23. Untuk keterangan lebih lanjut tentang keadaan-keadaan yang membawa kepada penguasaan Pulau Pinang rujuk R. Bonney, Kedah 1771-1821, The Search for Security and Independence, Kuala Lumpur, Oxford University Press, 1971, hlm. 52-78); (EICRRTSS, Vol. 1, f.3; K.G. Tregonning. "The Founding and Development of Penang 1786-1826," Tesis Ph.D., Universiti Malaya, 1965, hlm. 75). 
terhadap penguasian Burma ke atas siam dan kemungkinan tercetusnya peperangan Burmatsiam. (intuk mengelakkan kedah terseret dalam percaturan politik antara kedua-dua negara ini. Sultan Abdullah mendapati adalah bijak untuk mencasarkan P'ulau P'nang kepada Syarikat untuk memperolehi bantuan ketenteraan bagi mempertahankan kedah. ${ }^{-4}$ Sultan sebenarnya telah sanggup menyerahkan Pulau Pinang jika dibayar $\$ 30,(0)$ dolar Sepanyol setiap tahun sebaggai ganti rugi menyerahkan monopoli ke atas bijih timah, candu dan rotan. ${ }^{25}$

Satu hal yang menarik dalam kes ini ialah surat ini ditulis oleh Francis Light sendiri dengan tidak menyebut permintaan ketenteraan Sultan kepada kerajaan India. Daripada tiga pucuk surat yang dihantar oleh Francis Light, ${ }^{26}$ dalam surat kedua dan ketiga beliau menyatakan tujuan Sultan menyerahkan Pulau Pinang adalah kerana ancaman Belanda. $=$ Amat nyata Francis Light dengan sengaja tidak mendedahkan permintaan Sultan Kedah kerana khuatir Cakcutta tidak akan terima rancangan menguasai Pulau Pinang. ${ }^{28}$ Ini menjelaskan mengapa beliau tidak mahu menemui Sultan Kedah apabila baginda beberapa kali menjemputnya ke Kedah. ${ }^{29}$

24. $\quad S S R$ (IOL). Vol 2. ff. 33-36.

25. Sultan sebenarnya telah bertegas bahawa baginda hanya akan menerima 30 ribu dolar Sepanyol tetapi Francis Light mengesyorkan kepada Syarikat Hindia Timur Inggeris bahawa jumlah yang diminta oleh Sultan terlalu banyak dan menurutnya Sultan akan berbesar hati untuk menerima 10 ribu dolar (SSR(IOL), Vol. 3, ff. 2-3).

26. Surat-surat tersebut bertarikh 23 Januari, 1786, 5 Februari, 1786 dan 15 Februari, 1786.

27. ... Light described the Dutch attacks on Rian and Selangor bwilt up a pictwre of their growing infivence in the Straits of Malacca and gave his many reasows why he preferred Penang to Jwnk Coyton and Aceh "(Bonney, "Francis Light and Penang", hlm. 148). Beliau meminta majikannya Firma Madras-Jourdian, Sullivan dan De Souza menguasai Pulau Pinang sebelum ia dikuasai oleh Belanda atau kuasa-kuasa lain (Bonney, "Francis Light and Penang", hlm. 137). "He grimly warmed that if the firm nejected the proposals, the Swltan would twom to the Dutch or Dames and showld the Dutch have it they would possess the entire command of the whole streights (sic) " (Bonney "Francis Light and Penang". 1965, him. 148).

28. It wowld seem that Light deliberately made no mention of these fact for frar that Calcutto would not accept Pemang in onder mot to be dragered into a war with Burma or Siam. On the ather hand, what he did was to play wh the fwar of the grousth of Dutch in the Stratit, a fear to which the Company was particularty somsitive and to which it quichly nosponded" (Bonney, "Francis Light, the Nonya and Penang", hlm. 33). 
Sesungguhnya cita-cita Francis Lightlah yang menjadi faktor penting penguasaan ke atas Pulau Pinang. Ini dapat dilihat melalui tindakannya memajukan pulau ini sebagai pelabuhan bebas tanpa kebenaran kerajaan India; kekayaan yang diperolehi melalui sistem tanah bersama James Scott; penguasaan Pulau Pinang tanpa memaklumkan kehendak bantuan ketenteraan Sultan Kedah, Raja Abdullah kepada Gabenor Jeneral India dan pengetahuannya yang mendalam tentang halehwal dan kedudukan negeri-negeri Melayu.

\section{KEPENTINGAN MENARIK PEDAGANG-PEDAGANG TEMPATAN UNTUK MENGIMBANGI PERDAGANGAN NEGERI CHINA}

Tindakan Francis Light memajukan dasar perdagangan bebas dan pelabuhan bebas juga dipengaruhi oleh keinginannya untuk mengimbangi perdagangan dengan negeri China. ${ }^{30}$ Francis Light sedar satu cara untuk mengimbangi perdagangan China adalah dengan mengumpulkan hasil Kepulauan Melayu seperti timah, lada-hitam, sarang burung dan rempah-ratus. ${ }^{31}$ Barangan-barangan ini hanya akan dibawa oleh pedagang-pedagang Melayu ke penempatan baru ini. Francis Light berpendapat dengan memberikan kebebasan kepada pedagang

29. :.. explains why Light never had the courage to met the Sultan when the latter literally pleaded to him to come over to Kedah in 1786 and 1787 for consultations he always gave the excuse that he was busy" (Bonney, "Francis Light, The Nonya and Penang", hlm. 34).

30. SSR (IOL), Vol. 3, f. 60 .

31. Import utama Pulau Pinang adalah dari England dan India. Barangannya terdiri daripada piece goods (wollen, kapas dan kain sutera), barangan logam, ubat bedil dan besi. Barangan ini dijual di Pulau Pinang untuk hasil Kepulauan Melayu atau dikenali sebagai Straits produce seperti beras, timah, rempah-ratus, rotan, emas-urai, gading, ebony dan lada J. Bastin, "A Historical Sketch of The Circumstances which led to the Settlement of Penang and of the Trade to the Eastward Previous to, and since that Period", JMBRAS, Vol. 32, Pt. 1, 1959, hlm. 53). Sebahagian besar daripada barangan ini datang dari negeri-negeri yang terletak berdekatan dengan Pulau Pinang iaitu Burna, Semenanjung Tanah Melayu dan Sumatera. Mereka yang bertanggungjawab dalam membawa barangan ini ke Pulau Pinang ialah pedagang-pedagang tempatan. Untuk maklumat yang lebih lanjut tentang hasithasil bumi di negeri-negeri sekitar Pulau Pinang. rujuk S.G. Leith, A Short Accownt of the Settlement, Produce and Commerce of Prince of Wales Island in the Straits of Malacca, London, J. Barfield, 1804, hlm. 30. Rujuk juga SSR (IOL), Vol. 2, f. 10. 
Bugis dan Melayu. mereka akan berjaya mengumpulkan hasil Kepulauan. Melavi bernilai 9 juta dolar Sepanyol. ${ }^{32}$

Francis Light juga sedar akan bahaya yang ditempuhi oleh pedagang. pedagang tempatan di Kepulauan Melayu dan Selat Melaka pada penghujung abad ke-18. Menurutnya, pedagang-pedagang Melayu telah melalui pelbagai risiko yang besar untuk membawa barangan mereka ke Pulau Pinang. ${ }^{3 .}$ Mereka terpaksa melawan arahan Belanda dan sekatan raja-raja Melayu. Oleh yang demikian, segala galakan perlu diberikan untuk menarik mereka ke Pulau Pinang. Antaranya termasuk kebebasan pelabuhan, jaminan keselamatan. kemudahan beristirehat (convenient repository), kebebasan trafik dan layanan yang baik. ${ }^{34}$ Tambahan pula melalui dasar tidak mengenakan cukai diharapkan perdagangan tidak berpindah ke tanah besar yang terletak di luar kawalan Syarikat Hindia Timur Inggeris dan merupakan sarang lanun.

Rancangan tidak mengenakan cukai juga merupakan penyelesaian kepada kemungkinan membiaknya kegiatan lanun dan penyeludupan di Kepulauan Melayu. ${ }^{35}$ Kegiatan penyeludupan dikatakan menjadi-jadi di Kepulauan Melayu, khususnya di Selat Melaka apabila duti dikenakan ke atas perdagangan oleh

32. $\operatorname{SSR}$ (IOL), Vol. 4, ff. 8-9.

33. Light, still trading on his own account while Superintendent of the settlement, whas only too well aware of the advantages of keeping the port free since he was consciows of the practical difficulties that faced trade in the Straits of Malacca and the archipelago at the end of the eighteenth century and realised that every encouragement was needed if native merchants were to be attracted to Penang" (Courtenay, A Geography of Trade and Development., him. 66).

34. C.E. Wurtzburg, "A Letter from Captain Light to Lord Cornwalis", Dated 20th June, 1788", JMBRAS, Vol. 16, 1938, hlm. 115.

35. To lay a duty upon imports and exports, however small, will in some measurn retard the intention of Government, in rendering this Port a Magazine of Commerth The charge of collecting will consume the greatest part of the collections, and a spinit of smuggling will be introduced, whose Evils are innumerable" (Surat Kapten Light kepada Gabenor Jeneral India, Lord Cornwallis, 20. Jun, 1788, memetik dari Wurtzburg, "A letter from Captain Light...", hlm.115). 
kuasa-kuasa lain. Kegiatan penyeludupan berlaku bertujuan untuk menjual barangan berkenaan dengan kos yang rendah di kawasan lain. Dasar-dasar sekatan juga menyebabkan pemerintah-pemerintah tempatan memberontak dan pedagang tempatan lari ke kawasan-kawasan lain untuk menjual hasil mereka. ${ }^{3 h}$

Pada pandangan Francis Light, apabila kebebasan pemerintah-pemerintah tempatan dibendung daripada mendapatkan hasil melalui percukaian atau "hadiah", ini merintis jalan kepada penularan beberapa gejala yang lebih buruk. Menurutnya:

The Rajas deprived of their revenue which consisted in profits upon particular Articles of Commerce, Dutys and Presents, are constrained to procure a necessary maintenance of the Country, this introduces disaffection, complaint, jealousys and Broils and Piracys. ${ }^{37}$

Francis Light melihat perdagangan bebas dan pelabuhan bebas sebagai senjata yang dapat menjamin keuntungan yang besar dan sebagai alat untuk mengalahkan Belanda yang menjalankan dasar monopoli di Selat Melaka. Menurut Light, satu cara untuk memenangi pedagang-pedagang tempatan daripada cengkaman Belanda adalah dengan memberi jaminan keselamatan kepada pedagang-pedagang ini. $^{38}$

Pada masa yang sama dasar perdagangan yang bersifat liberal diperlukan kerana pulau ini tidak menghasilkan sebarang hasil pertanian yang menguntungkan. Barangan yang sesuai untuk dibekalkan ke China pula dibawa

36. 'Several of the Bugessee (sic) Princes established themselves in the Straits of malacca [sic), at Salaengore [sic], and Rheo [sic] for the conveniency of selling their own Manufactures and purchasing those of India" (Surat Kapten Light kepada Gabenor Jeneral India, Lord Cornwallis, 20 Jun, 1788, memetik dari Wurtzburg, "A letter from Captain Light..." hlm. 117)

37. (Surat Kapten Light kepada Gabenor Jeneral India, Lord Cornwallis, 20, Jun, 1788 memetik dari Wurtzburg, "A letter from Captain Light...", hlm. 121).

38. Did not the Dutch keep a strict watch over the Malass, most of them would leave Malacca; forty of them had prepared to come in the 'Drake', but were stopped by order of the (Dutch) Government; and not a man is allowed to leave Malacca without giving secuinty he will not go to Penang... The contempt and denision with which they treat this place, and the mean dirty ant to prevent people coming here, would dishonour any but a Dutchman" (L.A. Mills, "British Malaya 1824-1867", JMBRAS, Vol 33, Pt. 1960, hlm. 37). 
dari pulau-pulau sekitarnya. Oleh itu tindakan tidak mengenakan cukai merupakan satu-satunya penyelesaian bagi mengumpulkan hasil Kepulauan Melayu. Tambahan pula, jika cukai masih dikenakan, cukai ini tidak seimbang dengan risiko yang ditanggung oleh pedagang-pedagang tempatan untuk mengunjungi Pulau Pinang. ${ }^{39}$ Keadaan ini ditambah pula dengan sokongan yang diberikan oleh pemerintah-pemerintah tempatan kepada Francis Light. ${ }^{* 0}$ Ini berkemungkinan besar telah memberi keyakinan tambahan kepadanya untuk meneruskan falsafah perdagangan bebas di Kepulauan Melayu.

Tindakan menganjurkan dasar perdagangan bebas juga telah menjamin kemasukan pedagang-pedagang tempatan lain khususnya kaum Cina ke Negerinegeri Selat. Pedagang Cina yang telah biasa dengan dasar-dasar perdagangan bebas di Kepulauan Melayu mengalu-alukan langkah Negeri-negeri Selat memperkenalkan "Free Trade" ini."1

39. The Malays if they find goods in no greater variety here (Penang), than in a ship, and the profits reduced by Dutss (sic) equal to Malacca, will prefer going to a Port where they have wo risque, and where, tho' their Profits are small, they are sure of meeting with a great choice of Commoditys" (Surat Kapten Light kepada Gabenor Jeneral India, Lord Cornwallis, 20 Jun, 1788, memetik dari Wurtzburg, "A Letter from Captain Light...", hlm. 115).

40. "Notices of Pinang", JIA, Vol. 1858, hlm. 187-190.

41. Francis Light menggambarkan orang China sebagai "... the most valwable part of our inhabitants" (SSR (IOL), Vol. 6, ff 121-122). Kepentingan kaum Cina ini telah mendorong Penguasa Pulau Pinang, Phillip Mannington (1794-1795) meminta Gabenor Jeneral India, Sir John Shore menggalakkan penghijrahan kaum Cina dari Canton dan Macao. I most eamestly wish and initial your support in giving every encowragement to the importation of Chinese to the colony from Canton, Macao and it cannot be effected more forcibly than by your Select Committe and Resident Supercargoes there, to wse eany endeavow in their power to prevail, on all bricklayers, brick and file makers, stome cutters. carpenters, people concermed in every kind of agriculture, in particular merckants. Earny encowragement will be given to make themselves comfortable, and that the Company wils bear the expenses for three months after their arrival, will allot them any spot of growed they wisk to clear and cultivate free of Taxes or any dwties whatever for fowr years and will advance them a small swm of moncy to enable them to prosecwite their vieus (SSRTIOL). Vol. 7. ff. 230-231).

Mengikut Norman Macalister, Penduduk Pulau Pinang pada tahun 1800 ialah 30 ribu orang dan daripada jumlah ini, 12 ribu berbangsa Cina (N.Macalister, Histonical Momoto Relative to Importance Political and Commencial Submitted to the Honowralble The East India Company and the Gonernment and Lagislative of Great Britain, London. J.H. Hart. 1803, hlm. 22). 
Allen dan Donnithorne dalam buku, Westem Enterprise in Malaya and Indowesia menyifatkan kehadiran orang Cina di rantau Asia Tenggara sebagai flag followed the Chinese yang bermaksud mereka datang dahulu ke kawasan ini dan kemudian barulah diikuti oleh Inggeris. Kenyataan-kenyataan seperti ini memperkukuhkan lagi hujah bahawa tindakan mewujudkan pelabuhan bebas di Negeri-negeri Selat berkemungkinan besar adalah untuk menarik pedagangpedagang Cina. ${ }^{42}$

Seperti yang diimpikan oleh Francis Light, Pulau Pinang mengalami kepesatan perdagangan dan pertambahan penduduk sejak diterokai. Dua tahun selepas diduduki, penduduknya meningkat kepada 1,000 orang. ${ }^{43}$ Pada tahun 1793, penduduknya telah meningkat kepada 5,000 orang ${ }^{44}$ dan menjelang tahun 1804 jumlahnya meningkat kepada 12,000 orang. ${ }^{45}$ Antara tahun 1813-1825, penduduknya telah meningkat menjadi lima kali ganda. ${ }^{46}$ Dari segi nilai eksport

42. Lebih lanjut tentang peranan orang Cina, rujuk G.C. Allen dan A.G. Donnithorne, Westem Enterprise in Indonesia \& Malaya, London, 1957, hlm. 39; "Notices of Pinang"JIA, Vol. 5, 1851, hlm. 1-14; Vol. 6, 1852, hlm. 18-32, 150-151, 170.

43. $S S R$ (IOL), Vol. 3. f. 15.

44. Berhubung dengan bilangan penduduk di Pulau Pinang terdapat perangkaan yang berbeza-beza diberikan oleh sumber-sumber yang berlainan. Mengikut Skinner, penduduknya melebihi 10 ribu orang pada penghujung tahun 1789 dan lebih daripada 20 ribu orang pada tahun 1795 (A.M. Skinner, "Memoir of Captain Francis Light", JSBRAS, Vol. 28, 1895, hlm.4).

45. Leith, A Short Account of the Settlement..., hlm. 29.

46. Jumlah Penduduk Pulau Pinang dari Tahun 1813-1825

\begin{tabular}{ll}
\hline Tahun & Jumlah \\
\hline 1813 & 32,333 \\
1814 & 33,269 \\
1815 & 28,862 \\
1816 & 37,445 \\
1817 & 36,570 \\
1818 & 34,955 \\
1819 & 37,366 \\
1820 & 37,621 \\
1821 & 38,505 \\
1822 & 45,127 \\
1823 & 52,183 \\
1824 & 53,669 \\
1825 & 52,334 \\
\hline
\end{tabular}

Sumber: $S S R$ (SNL) (K5, f 72). 
dan import, nilainya pada tahun 1789 hanyalah $\$ 853,592$ dolar Sepanyol, tetapi menjelang tahun 1804 , jumlah ini telah meningkat kepada $\$ 1,418,200$ dolar Sepanyol.4:

Dengan ini jelaslah bahawa dengan menganjurkan dasar perdagangan bebas di Kepulauan Melayu, Light berjaya mencapai beberapa matlamat penting. ${ }^{4 *}$ Antaranya yang paling penting ialah beliau berjaya memenangi pedagangpedagang tempatan dan mengumpulkan hasil Kepulauan Melayu untuk kepentingan perdagangan dengan China. ${ }^{49}$

47. Leith, A Short Account, hlm. 57-59.

48. Langkah memajukan dasar perdagangan bebas dikatakan telah membawa beberapa faedah, antaranya:

(a) Penjualan candu dikatakan telah meningkat. Dahulunya perahu-perahu dari kawasan jauh tidak dapat datang ke Pulau Pinang untuk membeli barangan ini disebabkan pelbagai sekatan, tetapi kini kerana perdagangan bebas, ia dibenarkan. Pada tahun 1789, dikatakan 300 peti candu dijual di Pulau Pinang. Pengunaan tahunan candu di Pulau Pinang pada tahun 1808 dikatakan berjumlah 60 peti. Dua ratus peti lagi diagihkan dari Pulau Pinang ke kawasan-kawasan lain. Penggunaan candu Syarikat Hindia Timur Inggeris di Kepulauan Melayu untuk setahun dianggarkan berjumlah 1,000 peti. Dalam keadaan ini telah menjadi hasrat Inggeris untuk menjamin kebebasan kepada perahu-perahu dari Kepulauan Melayu untuk mendapatkan candu dari Pulau Pinang.

(b) Dasar pelabuhan bebas Pulau Pinang juga dikatakan menggalakkan orang-orang Melayu membuat pelayaran yang lebih menguntungkan tanpa halangan. Untuk setiap barangan yang di bawa, ia mempunyai pembeli (SSR(IOL). Vol. 4, ff. 1-6).

(c) Di Timur Sumatera dan pantai Semenanjung dikatakan terdapat pelbagai barangan dagang yang berharga seperti bijih timah, emas, perak, beras, lada hitam, damar, rotan, minyak, wax, gading, cassia dan lain-lain. Sebelum pembukaan Pulau Pinang, hasil-hasil ini tidak diendahkan dan penduduk di sini juga tidak tahu ke mana untuk di jual hasihasil tersebut. Sesungguhnya pembukaan Pulau Pinang telah membawa rahmat kepada mereka. They have now brought their goods to Penang, and find the produce of their land is no longer wseless..." (SSR(IOL). Vol. 4, ff. 1-6).

49. Export dan Import perdagangan tempatan Pulau Pinang melalui kapal-kapal Melayu dalam dolar Sepanyol adalah seperti berikut: 


\section{MELAWAN MONOPOLI BELANDA}

Tindakan Francis Light menganjurkan dasar perdagangan bebas dan pelabuhan bebas juga bertujuan untuk menyaingi Belanda. ${ }^{50}$ Menurut Francis Light, sejak penubuhan Syarikat Hindia Timur Belanda pada abad ke-17, Belanda telah memonopoli hampir keseluruhan perdagangan Eropah dengan Kepulauan Hindia Timur. $^{51}$ Betawi di pulau Jawa yang terletak di kawasan strategik untuk mengawal perdagangan telah dijadikan pusat kegiatan Belanda di Hindia Timur. ${ }^{52}$ Kapal-kapal China tidak dibenarkan masuk ke Selat Melaka tanpa mendapat surat kebenaran dari Betawi dan pedagang-pedagang Portugis juga harus membayar sejumlah wang tertentu untuk menggunakan Selat Melaka.

Belanda mengekalkan kekuasaan mereka di perairan ini pada tahun 1786 dengan menyediakan angkatan tentera yang dikatakan terdiri daripada 6 kapal perang, beberapa kapal pengawal dan banyak lagi kapal tambahan. ${ }^{53}$ Keadaan menjadi bertambah buruk apabila Belanda menawan Riau pada tahun 1784 . Riau sebelum ini merupakan satu-satunya pelabuhan Melayu yang menjamin

\begin{tabular}{crrr}
\hline Tahun & 1790 & 1791 & 1792 \\
\hline & & & \\
Import & 119,028 & 185,395 & 224,533 \\
Export & 123,949 & 136,466 & 317,414 \\
& & & \\
\hline Jumlah & 243,977 & 321,861 & 541,947 \\
\hline
\end{tabular}

Sumber: (T. Braddell, Statistics of the Population, Commerce, Agriculture, Revenve and Government Establishments of the British Settlements in the Straits of Malacca, Pinang. Pinang Gazette, 1861, hlm. 5).

50. -... the Dutch are seiring every vacant place, it wowld still be necessany to have a factory here, in onder to preserve a communication with the Malass and Bugwese and share some part of a profitable trade" (SSR (IOL), Vol. 2, f. 43).

51. PWTG, 12 Jun, 1819; SCCR, 8 Mac, 1832.

52. J.R Bruijn, "Between Batavia and The Cape:Shipping Pattern of the Dutch East India Company", JSEAS, Vol. 11, No. 2, 1980, him. 253.

53. Rujuk juga $P W I G, 12$ Jun, 1819. 
pelayaran yang selamat kepada pedagang-pedagang Inggeris dan kapal-kapal tempatan dari Kepulauan Maluku, Filipina, Borneo dan Sulawesi. Apabila Riau dikuasai oleh Belanda, keperluan untuk menguasai sebuah pelabuhan baru menjadi amat perlu. ${ }^{54}$ Syarikat Hindia Timur Inggeris juga kehilangan sebahagian besar perdagangan bijih timah Riau yang kini jatuh ke tangan Belanda. Riau juga merupakan pusat penjualan candu England. Jika satu kawasan yang strategik tidak dicari untuk pedagang Bugis membeli candu England, maka England harus melupakan sahaja hasratnya untuk memonopoli perdagangan Melayu yang akan dimonopoli sepenuhnya oleh Belanda. ${ }^{55}$

Dapatlah dikatakan bahawa penguasaan Pulau Pinang merupakan percubaan serius England untuk memusnahkan monopoli Belanda di kepulaun sebelah Timur. Kenyataan ini menggambarkan dengan jelas mengapa Pulau Pinang harus dijadikan sebuah pelabuhan bebas. ${ }^{56}$ Tidak dapat dinafikan bahawa tindakan Francis Light menguasai Pulau Pinang telah memenuhi matlamat

54. Keperluan untukmenguasai sebuah penempatan baru juga bertujuan untukmemulihkan semula perdagangan orang-orang Melayu dengan Inggeris. "It therefore became more thax ever necessany for the English to establish a fortified settlement in the vicinity of the Straits. so that the Malay Powers might be encouraged to resume commercial relations and be protected from the vengeance of the Dutch" (A. Aspinall, Cornwallis in Bengal, The Administratice and Judicial Reforms of Lord Comwallis in Bengal, Together with Accounts of the Commercial Expansion of the East India Company, 1786-1793, and of the Foundation of Penang. 17861793, London, Manchester University Press, 1931, hlm. 197. Rujuk juga Swmatra Factory Records, selanjutnya SFR, Vol. 30. ff. 341-342.

55. The English Company 5 rivalny with the Dutch, and the loss of their cargoes of spices and tin for the Chima trade, were, therefore, additional incentives to take Penans. They hoped that the new settlement would soon become the emporium of the castern com merce', by wich the trade of Bengal and the west parts of India will be connected with that of Chimo" (Aspinall, Commallis in Bengal.., hlm. 197). Rujuk juga SSR (IOL). Vol. 2, ff. 6566 .

56. Dalam surat Francis Light yang bertakrih $10 \mathrm{Jun}, 1787$ beliau telah menegaskan bagaimana Pulau Pinang akan dapat berkembang maju jika kerajaan memberi perlindungan kepadanya. Menurut beliau. ... sitwated advantageousty for commerre.. it



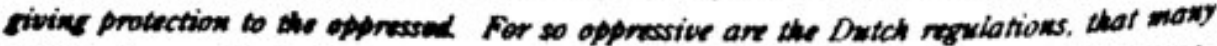

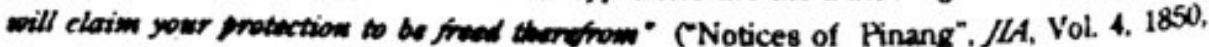
hlm 638). 
serampang dua mata. Pertama, berjaya memecahkan dominasi Belanda dan kedua, memenangi sokongan pemerintah-pemerintah tempatan. ${ }^{37}$

\section{KETIDAKSESUAIAN PULAU PINANG UNTUK KEgIATAN PERTANIAN}

Setelah menyedari hakikat bahawa Pulau Pinang tidak mempunyai sebarang hasil untuk perdagangan eksport, Francis Light bertindak memajukan dasar perdagangan bebas dan pelabuhan bebas. Pada peringkat awal, tanaman seperti padi, buah-buahan, kelapa, gambir dan tebu telah diusahakan dengan giat tetapi tidak dieksport. Hanya pada tahun 1804 barulah Pulau Pinang mengeksport lada hitam bernilai 400,000 dolar Sepanyol dan pinang bernilai 240,000 dolar Sepanyol. Dua lagi tanaman jualan, iaitu kopi dan kapas diperkenalkan pada tahun 1808 dan 1813 tetapi tidak berjaya. Oleh itu pada peringkat awal penguasaan Pulau Pinang, Francis Light berpendapat pemansuhan cukai sepenuhnya merupakan cara terbaik untuk mendapat hasil eksport dari negerinegeri di sekitarnya. Sehubungan dengan ini pentadbirannya juga diubah suai dengan bercirikan Laissez-Fair $e^{58}$ untuk mendatangkan pendapatan yang lebih.

57. The aquisition of Prince of Wales Island may therefore be said to mank the beginning of a serious attempt on the part of the English to destroy the Dutch mowopoly of trade in the eastern archipelago: a monopoly which had excited the resentment of European rivals, as well as the hatred and fear of the petty Malay Powers whose trade was arbitrarily regulated from Batavia and Malacca" (Aspinall, Comwallis in Bengal.., him. 198).

58. Laissez-Faire dalam konteks Pulau Pinang merujuk kepada dasar-dasar liberal dalam perdagangan dan pentadbiran yang diperkenalkan semata-mata untuk menarik pedagangpedagang tempatan dan asing. Untuk memenangi kaum Cina, England menggalakkan mereka membentuk kesatuan mereka sendiri tanpa mencampuri urusan mereka.

So free from intsome restrictions was British nule, that they (Chinese) almost fongot, that they were in a foreign country, and loaked upon Powang and Singapore as Chinese cities. the administration of which was left in British hands. With wo desire to asswme the meansome task of goverwing themselves and indifferent to wato nied them so long as their business was not interfered with, they reganded the British as inerplicable philamtropists who for some quite indiscournable motive took all the burdens of administration off their showlders, and left them at full libenty to make as wuch monoy as they chose" (Mills. "British Malaya", JMBRAS, Vol 3, Pt 2, 1925, hlm. 438). Hal ini juga diakui oleh Sandhu. 
Apabila Gabenor Jeneral India, Lord Cornwallis mencadangkan Syarikat Hindia Timur Inggeris harus mengenakan duti import di Pulau Pinang, Light menegaskan cukai seumpama ini tidak akan menggalakkan perdagangan. Menurut Light:

... as this island [Pulau Pinang] produces nothing of a commercial nature in itself, but every article fit for the Chinamarket to be procured as it is brought from the surrounding countries by the Malays, whose chiefinducement to visit it has been the Great Freedom of trade, that inducement ceasing, the imports would become too inconsiderable to defray the expence of collecting duties on them.... it cannot be expected, that a revenue can be raised at a early period equal to the charges of Government. A little more time, when the trade is extended and become established by proper support and encouragement, may than show the Honourable Company the advantages resulting from the island.... ${ }^{59}$

Dasar liberal dalam perdagangan ini juga bersesuaian dengan kehendak pedagang-pedagang Pulau Pinang. Pada 19 Mei, 1796, Major Macdonald, Gabenor Jeneral Pulau Pinang membentuk sebuah jawatankuasa untuk melaporkan perdagangan Pulau Pinang..$^{60}$ Dalam laporannya jawatankuasa

menurutnya, British rule and laissezfaire trade policy, with which the Chinese had come into contact elsewhere in South-East Asia and which they viewed favourably, accounted for the transfer of numerous Chinese from Malacca to Penang" (K.S. Sandhu, "Chinese Colorization of Malacca, A Study in Population Change 1500-1957 A.D", JTG, Vol. 15, 1961. h.lm. 6-7). Jackson pula menyebut, "One of the basic attractions of the Straits Settlements from the Chinese point of view was the laisserfaire attitude adopted by the British towands the immigrants. For much of the nimeteenth century the Chinese were left almost entirely to themselves and were governed throwgh headmen, or Captain China, whom they themselves appointed own internal onganization distinct from, and almost completely lacking in integration with the British administrative framework; in short the Chinese established an imperium in imperio in the British settlements" J.C. Jackson, Planters and Speculators, Chinese and European Agricultural Enterprise in Malaya, 1786-1921, Singapore, Craftsman Press, 1968, hlm. 3). Untuk lebih lanjut rujuk juga EICRRTSS, Vol. 1, f. 3; Notices of Pinang" JLA. Vol. 5, 1851, hlm. 1-14.

59. (SSR (IOL), Vol. 3). Untuk lebih lanjut rujuk juga Aspinall, Comvallis in Bengah..,hlm. 204-205.

60. Jawatankuasa ini diwakili oleh Messrs McIntyre, Scott, Lindsay, Hutton, Roebuck. Young. Brown, Sparran, Mackrell dan Nason ("Notices of Pinang". JLA, Vol. 5, 1851. hlm. 97). 
menentang rancangan mengenakan cukai dengan alasan barangan yang dikumpulkan di pulau tersebut adalah dari kawasan sekitar dan tidak praktikal untuk dictukai. ${ }^{\text {t: }}$

Dalam keadaan ini satu-satunya cara untuk mengumpul kekayaan di Negerinegeri selat ialah dengan menganjurkan dasar perdagangan bebas dan pelabuhan bebas.

\section{PERANAN STAMFORD RAFFLES DAN CITA-CITA RAFFLES UNTL K MENGUASAI TIMUR}

Tindakan Stamford Raffles memajukan dasar perdagangan bebas dan pelabuhan bebas adalah berlatarbelakangkan cita-citanya untuk membina sebuah empayar di timur dengan memajukan Singapura sebagai sebuah pelabuhan bebas. Beliau ingin menjadikan Singapura sebagai batu loncatan untuk

61. ... the committee argued forcibily against taxing the trade of the island, as consisting wholly of the produce of other countries, which it is the grand object to induce to be brought and which taxation might scare away, they point out it is the extent of the exchange-trade which gives life, activity, riches, population and cultivation to Finang. The laying restraints thereon, if but swspected that it might lessen the trade, could not be deemed politic. That by a free exchange, the increase of population, capital and cultivation would present a taxable subject, in the faming the exclusive sale of luxuries to a rich and great population, and a duty on the net produce of an extensive and valwable cultivation "'Notices of Pinang", JIA, Vol. 5, 1851, hlm. 98). Keperluan untuk Pulau Pinang muncul sebagai pelabuhan bebas juga digesa oleh James Scott. Menurutnya Pulau Pinang harus dijadikan pelabuhan bebas semata-mata untuk berfungsi sebagai pusat pertukaran untuk kawasan-kawasan sekitar. ... Pinang, at least for the present, be declared a free Port. This will appear wise when it is Considered that the trade is not an impont or conswmpt; nor an Export of Produce, but a gain in Exchanges of others; and it seems wiser to trust to a swre Revenue from an Encrease of Capital and Population consequent to a free trade, that trust to one on a passing commodity which impediments may move elsetwhere: as every duty will hurt more in repressing an import of people and capital than it will benefit in immediate receipts-Besides, the ham done is permanent, the benefit only occasional and vwcertain" (Fielding. "The Settlement of Penang...", hlm. 47). Rujuk juga SSR(IOL), Vol. 7. ff. $264-265$. 
menyempurnakan impian ini. ${ }^{22} \mathrm{Hal}$ ini jelas terbukti daripada surat-suratnya apabila beliau sering menyamakan dirinya dengan Napoleon. Oleh itu tidakiah keterlaluan untuk dikatakan bahawa tindakannya mengadakan pelabúhan bebas dan perdagangan bebas adalah berpunca daripada cita-cita Raffles untuk membina sebuah empayar.

Cita-cita ini dapat direalisasikan oleh Raffles hasil pengalamannya berkhidmat di Kepulauan Melayu selama 19 tahun dan minatnya sendiri untuk memahami keadaan di Kepulauan Melayu. ${ }^{63}$ Raffles mempunyai maklumat terperinci tentang Kepulauan Melayu. ${ }^{6 \star}$ Berdasarkan pengalamannya, Raffles

62. The West poured into the Far East, effecting an undreamed of change, the tranformation of the whole East by western science, the birth, in fact, of the modem world. Of this Raffles had a glimpse, Singapore was the first, the essential, step towards events of the world magnitude. Its foundation was part of a sequence-the Nile, Trafalgar, Waterloo. The stage was setfor Europe's decisive incursion into East Asia. Old Asia was to disappear, a new Asia to be borm. the Asia of the Modern World such were the forces which Raffles set in motion by founding Singapore" (M.Collis, Raffies, London, Faber and Faber, 1966, hlm. 219).

63. Thomas Stamford Raffles dilahirkan di pelabuhan Jamaica pada 5 Julai, 1781. Tempat lahirnya berkaitan dengan perdagangan yang bakal diperluaskan oleh Raffles. The place of his birth was appropriate; for Thomas Stamford Raffle's carrer was to be associated with the expansion of British trade in the tropics (E. Hahn, Raffies of Singapore. Kuala Lumpur, University Malaya Press, 1968, hlm. 1). Kerjayanya pula bermula pada tahun1795 apabila beliau menjadi kerani di India House. Pada tahun 1805, Raffles menjadi pembantu Setiausaha kerajaan Pulau Pinang. Pada tahun 1807, beliau menjadi agen Gabenor Jeneral untuk Eastem Seas dan pada tahun 1811, dilantik sebagai Leftenan Gabenor Jawa sehingga tahun 1816. Pada tahun 1818, beliau dilantik sebagai Leftenan Gabenor Bangkahulu (C.M. Turnbull, A History of Singapore, 1819-1975, Kuala Lumpur. Oxford University Press, 1977, hlm.6). Sepanjang kehadirannya di Kepulauan Melayu. beliau memperkenalkan dasar-dasar liberal dalam bidang pentadbiran, ekonomi dan sosial. Paling ketara ialah pengisytiharan beberapa buah pelabuhan bebas. Pada 7 Disember. 1803 beliau memajukan semula Balambangan sebagai pelabuhan bebas (G. Miller, "Robert Farquhar in the Malay World", JMBRAS, Vol. 51, Pt. 2, 1978, hlm. 136). Pada tahun 1818, beliau mengisytiharkan Bangkahulu sebagai pelabuhan bebas ("Notes Illus trative of the Life Services of Sir Stamford Raffles" JLA, 1855, hlm. 306-310). Pada tahun yang sama sebuah lagi pelabuhan bebas dibuka di Samangka Bay di Selat Sunda (RJ Wilkinson, "More on Bencoolen", JMBRAS, Vol. 19, Pt. 1, hlm. 112). Rafiles meninggal dunia pada 5 Julai, 1826.

64. Singapore Chromiclec selanjutnya SC 13 Januari, 1831. Untuk lebih lanjut rujuk juga Rafles Collection, selanjutnya RC, Vol. 2:1-29, 47-53; Vol. 11, hlm. 207. 
telah mengklasifikasikan negeri-negeri Melayu kepada sembilan bahagian untuk memudahkannya meluaskan pengaruh. ${ }^{65}$ Untuk memastikan England dapat bertahan lebih lama di Kepulauan Melayu, Raffles telah menyarankan dasar menjalinkan hubungan yang mesra dengan pemerintah-pemerintah tempatan melalui perjanjian, tidak kira sama ada daerah-daerah berkenaan diserahkan kembali kepada Belanda ataupun tidak. ${ }^{66}$ Sewaktu Raffles berada di Kepulauan Melayu beliau telah menulis surat kepada pemerintah-pemerintah tempatan untuk menjalinkan hubungan yang mesra dengan memberikan pelbagai persembahan. Pemerintah di Banjarmasin, Pontianak dan Brunei juga telah memohon untuk mengadakan hubungan diplomatik dengan Inggeris. Sultan Pontianak dan Brunei telah membuat permintaan mendapatkan perlindungan Inggeris pada tahun 1803 dan 1810. Pemerintah Jawa pula telah memohon perlindungan Inggeris untuk menentang Belanda pada 6 Julai, $1818 .{ }^{67}$ Sewaktu Raffles menjadi Gabenor Bangkahulu penduduk tempatan telah meminta bantuannya untuk menghapuskan kegiatan perhambaan. ${ }^{68}$ Sepanjang kehadiran Raffles di Kepulauan Melayu beliau telah bersungguh-sungguh dalam usahanya

65. The various groups of states to which what may be emphatically termed our Malay policy may extend, are the following:

1. The states of the Malay Peninsula

2. The states of the Island of Sumatra

3. The states of the Island of Bomeo

4. The states of the Sunda Isles, comprehending the chain of islands which extend form the Stratis of Sunda to Timor and Celebes, exclusive of Java.

5. The states of Celebes

6. The states of Sulu and Mindanawa

7. The states of Moluccas comprehending Ceram and Banda

8. The states of Jilolo or Little Celebes

9. The Black Papwa States of the New Gwinea and The Papwa Islands in the vicinity (RC, Vol. 2:27).

66. -...it will probably appear to be our sowndest policy to form the most intimate conmections by treaty with thase which have indisputable pretentions to independence. This Aolicy will I flatter myself appear obviows whether we contemplate the maintaining the Malay Isles in permanent pasession, or the passible tramsfering the Dutch passesions the cuent of a peace in Exrope (RC, VoL2 h/m. 27). Rujiuk juga "Colowization of The East-

em Archipelago" dalam (Raffles Printed Sowres Vol. 1, hlm. 33).

67. SFR, Vol. 47, f. 408.

68. SC, 24 April, 1828. 
menghapuskan kegiatan perhambaan. ${ }^{*}$ Ini terbukti daripada proklamasi Nombor V, 1823 yang mengharamkan kegiatan hamba di Singapura. ${ }^{70}$

Raffles juga dikatakan mempunyai sifat-sifat yang disukai oleh penduduk tempatan. Sewaktu melawat Sumatera pemerintah-pemerintah tempatan di situ telah memohon bantuannya:

During the tours Raffles made in May, June and July 1818, the chiefs of the various Sumatra tribes became attracted to him, partly because his manner with them was so easy and pleasant, and also because he was abolishing practices which were oppressive. It is recorded that when he left their territories some of them wept to see him go. They were within the Dutch sphere and humbly asked for British protection. ${ }^{71}$

Tindakan penduduk tempatan memohon perlindungan Inggeris juga bertujuan untuk menentang dasar monopoli Belanda. Raffles sebagai seorang liberal abad ke-18 mendapati dasar-dasar Belanda membendung kebebasan individu dan dasar perdagangan mereka pula bertentangan dengan falsafah Adam Smith yang menegaskan setiap individu mempunyai "... the desire to be free, a sense of propriety, a habit of labour and propensity to truck, barter and exchange ..." "72 Raffles menentang monopoli tradisional Belanda dan menyokong dasar perdagangan bebas. Menurutnya:

Commerce is like liberty and will not bear unjust control. Dutch is a jealous power and refuses her blessings to all who would sustain her course - the commerce is the object of our establishment in these seas, why should monopoly exist? Why should the advantages of trade be all on one trade and none on the other... commerce should prosper, it is essential that advantages should be reciprocal - why then create and maintain barriers which are directly in the way of the objects we wish to attain. ${ }^{73}$

Harapan Raffles ialah apabila penduduk tempatan dibebaskan daripada belenggu monopoli Belanda, mereka akan mempunyai kebebasan untuk membeli dan menjual di pasaran yang bebas. Kebebasan ini juga akan membolehkan mereka meningkatkan kedudukan ekonomi dan membeli

69. Papers Relative to Stamford Raffles and Java, 1814, hlm. 50. Rujuk juga PWIG, 12 Jun. 1819.

70. $S S R$ (SNL), L17, ff. 284-292.

71. M. Collis, Raffies, London, Faber and Faber, 1966, hlm. 129.

72. E. Roll, $A$ Histony of Economic Thought, London, Faber and Faber Ltd., 1953, hlm. 146.

73. SFR. Vol. 49, f. 517. 
barangan England. it Berdasarkan pengalaman Raffles di Kepulauan Melayu beliau mendapati dasar perdagangan Belanda menyebabkan pemerintah Melayu berpecah dan menjadi punca kepada pembentukan negeri-negeri kecil dan berkembangnya kegiatan lanun. ${ }^{75}$

Penerimaan Melaka oleh Inggeris dari tangan Belanda pada tahun 1795 telah menyaksikan pemansuhan dasar-dasar monopoli Belanda. Inggeris telah menarik balik larangan ke atas perdagangan persendirian seperti candu, rempahratus, timah, pakaian dan lada. Turut dimansuhkan ialah cukai ke atas penjualan ikan, buah-buahan, sayur-sayuran dan beras. Tindakan ini merangsangkan perdagangan dengan beberapa buah negeri pengeluar bijih timah di sekitar Melaka. Sesungguhnya dasar-dasar liberal yang telah diperkenalkan sebelum kehadiran Raffles telah menyebabkan dasar-dasar liberalnya ${ }^{76}$ diterima dengan lebih terbuka.

Jelaslah bahawa tindakan Raffles mempelopori dasar perdagangan bebas dan pelabuhan bebas adalah berasaskan kefahamannya terhadap kehendakkehendak penduduk tempatan dan setelah diperkenalkan dasar-dasar yang liberal di Kepulauan Melayu. Raffles merumuskan kemampuan England untuk berdiri tegak di Timur adalah semata-mata kerana dasar liberal. ${ }^{\pi}$

\section{SFR, Vol. 49, f. 714.}

75. $\quad$... European policy which first destroyed the independence of their more respectable states and sebsequently appropriated to itself the whole trade of the Archipelago, left them without means of homest subsistence, while by the extreme severity of its tortures and punishments it drove them to a state of desperation. Thus piracy became honourable. and that devotion which on another occasion would have been called a tirtue became a crime" (SCCR, 27 Disember, 1832). Untuk lebih lanjut rujuk surat Raffles kepada William Petrie. Esquire Gabenor dalam Konsul, Prince of Wales Island, 18 Februari, 1814 dalam "Raffles and the Indian Archipelago" (VLA (N.S.), Vol.1, 1856, hlm. 266-290).

76. Berhubung dengan dasar-dasar liberal Raffles di Kepulauan Melayu rujuk J.Bastin. Statement of the Services of Sir Stamford Raffles, Kuala Lumpur. Oxford L'niversity Press. 1978, hlm. 6-27; E. Hahn. Rafites of Singapore, hlm. 74-79, 110-115: "Notes Illustrative of Life and Service of Sir Stamford Raffles". JIA, 1855, hlm. 307-309, Sophia Raffles, Memoir of the Life.., hlm. 42-56; H.RC. Wright, The Freedom of Labour Under Raflles Administration in Java 1811-1816, - JMBRAS, 1953. Vol. 26, Pt. 1. hlm. 105-110. 77. The swpremacy of Great Britain having now been stablished over the whote of the continent of India, and onr Empire consolidated by the late temitorial acquistitions and by the liberal principles and enlightened policy watich have rasied it to the present pitck of whrivalled eminemce and prosperity" (SFR. Vol 50, t. 41). 
Matlamat Kaffles memajukan davar perdagangan bx-bas juga be rtujuan untuk menarik pedakang pedapang tempatan dari welabuhan pelabuhan fe-landa S.belum ke.datangan kuasa Barat, Bantam dan Ace-h me-rupakan dua buah pusat perdagangan penting di Kepulauan Melayu. ()engan ke-hadiran Be-landa kedudukan Bantam diambilatih oleh Pretawi dan dasar-dasar lselanda juga dikatakan telah menamatkan kedudukan Melaka. Ke-pulauan Malıku telah dibendung kenaikannya apabila Be-landa me'ndirikan pe'ne'mpatan di Makasar. Menurut Raffles, apa yang diperlukan ialah polisi yang be-rlawanan untuk menarik perdagangan ke pelabuhan entrepot P'ulau l'inang dan Singajura. ${ }^{7 *}$ Justeru itu Raffles berpendapat dasar yang sebaiknya digunakan untuk memajukan perdagangan ialah dengan memperkenalkan perdagangan bebas.

... our establishments should be directed to no partial or immediate vieus if cummercial profit but to the presenvation iffree and unrestricted commerce, and to the encouragement and protection of individual enterprise and the interests of the general merchant."

Bagi Raffles penubuhan pelabuhan-pelabuhan Inggeris di timur haruslah dilihat sebagai memenuhi matlamat perdagangan bebas dan bukan untuk meluaskan kuasa. Beliau menambah, berasaskan prinsip inilah Singapura dan Bangkahulu diisytiharkan sebagai pelabuhan bebas. Tindakan ini dipercayai akan memajukan perdagangan Inggeris dan mewujudkan persaingan yang sihat. ${ }^{\text {* }}$

78. Thus by the possession of Penang and Singapore we have the means of reviving and reestablishing at least two of the ancient emporia" (Wurtzburg, Raffles of the Eastem Isles, him. 550-551).

79. SFR, Vol. 50, f. 30.

80. "All establishments to the Eastward must be looked upon as an entry for these purposes (melwaskan perdagangan), and these purposes alone. They are to be considered as so many outposts or stations erected for the convenience and security of our general commercial interest and not as Government intended for the nule and detailed management of a dominion. On these general principles the port of Singapore has been declared fiee, and no duties or restrictions whatever have been allowed to be imposed on commerce- The same principle has been extended to Bencoolen and I skall here after have occasion to advert to the necessity which exist of establishing the same throwghowt owr Eastem Establishment, as the only and the most effectwal means of improving our commerce, and affording a fair chance of competition and successful rivaln ${ }^{*}$ (Surat Raffles kepada Setiausaha Syarikat Hindia Timur Inggeris di London pada 28 Disember, 1819 SFK, Vol. 50, f. 31). 
Raffles sedar bahawa untuk menarik pedagang-pedagang tempatan ke Singapura, pelabuhan tersebut perlu dikecualikan daripada cukai. ${ }^{x !}$ Kaffles juga percaya perdagangan bebas akan membantu mewujudkan satu sistem yang seragam di seluruh Kepulauan Melayu. ${ }^{2}$

Free trade for Raffles was a thing of the future. What he regarded as a liberal element in his economic policy was the idea of establishing a uniform system of regulations throughout the whole Archipelago, by means of fixed ports. These would prevent Arabs, Chinese, Americans and other unprincipled adventurers from undermining British interests in the islands. ${ }^{83}$

Sejarah telah membuktikan kebenaran ramalan Raffles. Ramalan beliau dapat dilihat dengan nyata apabila Singapura dimajukan sebagai pelabuhan bebas dan berjaya menarik pedagang dan kapal dagang daripada semua bahagian Kepulauan Melayu. Menurut laporan Raffles pada 23 Jun, 1819 tiga bulan setelah Singapura dimajukan tidak kurang 167 buah kapal telah masuk ke pelabuhan tersebut. Ini termasuklah kapal-kapal kecil dari pelabuhan Riau yang bilangannya hampir-hampir seratus buah. Adalah dikatakan ramai duta dan pembesar Melayu ke Singapura mengucapkan tahniah di atas penguasaan Singapura dan mengharapkan perlindungan dan pakatan British. Antaranya yang paling ketara adalah permintaan daripada pemerintah Trengganu dan Kelantan.

From Tringano I found in the harbour one of the Sultan's vessel which his Highness had despatches with Rui/sic/ and other supplies immediately on having our establishment. This state is one of the most important on the Eastem side of the Peninswla and has hitherto escaped the infunence of the Dutch; the Sultan and principal chiefs availed themselves of this occasion to express their antriety and desire to cultivate a more intimate and closer connection with our Govermment. The same ancicty has been expressed on the part of the chief of Kalantan/sic/ a rising and fourishing state lying betwoen Tringano and Siam The people of these countries seem to consider the British alliance and protection essential to their interest and prosperity. a

81. SC, 16 Disember, 1820 .

2. Lebih lanjut rujuk Sophia Raffles, Memoir of $7 \mathrm{~m}$ Lit, hlm. 77.

83. J. Bastin, "Raffles and British Policy in the Indian Archipelago 1811-1816". MMBRAS,

Vol, 27, Pt. 1, 1954, hlm. 91.

8. Laporan Raffles dari Singapura pada 22 Jun 1819. SFR. Vol. 47, f. 807. 
Sehubungan dengan ini juga jumlah perdagangan dan penduduknya bertambah. Tidak sampai setahun selepas Singapura diasaskan kapal-kapal dari Siam, Cambodia, Kelantan. Terengganu, Pahang, Brunei, Borneo Selatan, Sulawesi dan Timur Sumatera mendarat di Singapura. ${ }^{* 5}$ Singapura juga telah menjalin hubungan perdagangan dengan China, negara-negara Eropah, Amerika, India, Jawa, Sumatera, Bali dan Kepulauan rempah. Barangan yang diperdagangkan pula meliputi rempah ratus, bijih antimoni, candu, sutera, rotan, habuk emas dan lain-lain.

Raffles sendiri pernah berkata bahawa lokasi Singapura cukup sesuai untuk menarik pedagang-pedagang Siam, Cambodia, Champa, Cochin-China dan China. Menurutnya setiap kali para pedagang berkunjung ke rantau ini, Selat Singapuralah yang menjadi tarikan. Beliau menambah jika pasaran boleh ditemui untuk barangan mereka sewaktu mereka ke sini, maka sudah tentu tidak akan mendorong mereka bergerak ke tempat yang lebih jauh, atau yang lebih mahal seperti Betawi. Menurutnya lagi, Siam kini menjadi pusat perdagangan penting di utara dan secara pesat meluaskan perdagangan tempatannya dan adalah dipercayai keseluruhan perdagangan akan berpusat di Singapura. Singapura menurutnya memendekkan tempoh waktu pelayaran kepada kurang daripada enam hari, iaitu tempoh waktu yang sama yang diperlukan untuk belayar ke sini dari Betawi, pantai Borneo dan Pulau Pinang. ${ }^{86}$

85. Mengikut akhbar Singapore Chronicle, bertarikh 27 Mac, 1828 dalam masa 3 bulan selepas Singapura diisytiharkan sebagai pelabuhan bebas perdagangannya berkembang pesat dan pendapatan yang diperolehinya juga meningkat. That in the year 1819, the settlement of Singapore, at that time resorted to chiefly by pirates, was taken possesion off by the British Govermment and made a free port; and in 1827, its import trade amounted to 13,387, 185 sicca nupess, with a corresponding export thus showing the extensive benefits to be derived from a free commercial intercource and altogether affording a greatly increased and increasing field of empolyment for British shipping: Taraf pelabuhan bebas Singapura juga membawa faedah kepada kapitalis England, Menurut John Bull, *Iam glad to find that Singapore is (has) become an object, to which English capital is devoted, all the way from home. English capital is now building houses and godowns at the extremity of the Malay Peninsula, while the capitalist is enjoying himself in England, and I hear it is paying him well. Jwdging indeed, of the future by the past, there is no place in the world, that promised to rise into greater importance than Singpore, as a Commercial depot and place of resort" (SC, $15 \mathrm{Mac}, 1827)$.

86. Singapore Daily Times merumuskan kemajuan Singapura sebagai perubahan dari sarang lanun kepada blooming colony (SDT, 15 Mei, 1879). 
Melalui penguasaan Singapura juga pedagang-pedagang Cina telah berjaya dimenangi. Masyarakat Cina sebelumnya telah terlibat dalam penanaman gambir dan lada hitam yang berpusat di Riau. Apabila Singapura dibuka, pulau ini berjaya menarik mereka pada kadar yang pesat pada awal tahun 1820-an. Menurut Raffles, dalam masa dua tahun Singapura diasaskan, tidak kurang 2,889 buah kapal telah mengunjungi pelabuhan tersebut. Daripada jumlah ini, 383 buah dimiliki oleh bangsa Eropah dan 2,506 buah lagi oleh pedagang tempatan. Jumlah barangan yang dibawa oleh penduduk tempatan dianggarkan berjumlah lima juta dolar Sepanyol dan oleh kuasa Eropah pula tidak kurang daripada tiga juta dolar Sepanyol. ${ }^{87}$

Kebanjiran penduduk di Singapura diharapkan dapat menjamin pemasaran barangan India dan England. Seperti yang diramalkan, Singapura telah mengalami pertambahan penduduk yang pesat sejak diasaskan. ${ }^{88}$ Mengenai pertambahan penduduk, Raffles telah merujuk kepada pelabuhan Jamaica sebagai contoh. Apabila beliau memajukan Bangkahulu sebagai pelabuhan bebas, dikatakan bahawa pelabuhan ini berpotensi untuk menarik dan mengekalkan penduduk yang ramai. Di samping itu dikatakan juga ia dapat menyerap modal yang banyak. ${ }^{89}$

Dalam kes Singapura, dengan menjadikannya sebuah pelabuhan bebas, adalah diharapkan ia akan dapat menarik pedagang-pedagang dari Timur untuk membeli barangan England dan India.

Raffles clearly grasped the commercial value of the Archipelago to Britain and British India, With a base at Singapore, the Indian cotton manufacturing industry, excluded in Europe by unfavourable tariff, might be able to develop a langer and more permanent market in the Archipelago. When the Indian industry began to crumble with the onslaught of cheap British cotton goods, Raffles saw wo reason why the in habitants of the Archipelago and even the millions of Chinese be not clothed from the cotton mills of Britain.

87. $S S R$ (SNL), L2, f. 3; , Vol. 49, f. 6-7.

88. SSR (SNL), Series, AA7, Januari, 1835-Disember, 1836, Singapore: Letters to Governors, f. 217.

89. Surat Raffles kepada pengarah Syarikat Hindia Timur Inggeris pada tahun 1821, SFR, Vol. 48, ff. 95-96.

90. Wong Lin Ken, "The Trade of Singapore 1819-1869, "JMBRAS, Vol. 33, Pt. 4. 1960, hlm. 27. 
Seperti yang diramalkan oleh Raffles, pada pertengahan tahun 1819 penduduk Singapura telah meningkat kepada kira-kira lima ribu orang. Menjelang tahun 1822, penduduknya dikatakan telah meningkat kepada kirakira 10 - 12 ribu orang.91 Taraf pelabuhan bebas Singapura telah memesatkan kebanjiran penduduk dari kawasan-kawasan lain. ${ }^{92}$ Pedagang Cina dari Selatan China yang sebelumnya berkunjung ke Melaka, Brunei dan Manila mendapati Singapura lebih selamat dan menguntungkan. Satu hal yang nyata ialah, Singapura telah menarik ramai penduduk dari Melaka yang ketika itu dikuasai oleh Belanda. ${ }^{93}$ Di samping itu status pelabuhan bebas ini juga berjaya menarik para pedagang dari pelabuhan Betawi ke Singapura. ${ }^{94}$ Kedatangan mereka adalah untuk mendapatkan barangan kapas yang mana jika dibawa ke Betawi dalam kapal British akan dicukai dua kali ganda. Status pelabuhan bebas Singapura telah memungkinkan komoditi ini diangkut ke Betawi tanpa dikenakan cukai. ${ }^{95}$

91. Saw Swee Hock, "Populations Trends in Singapore 1819-1967", JSEAH, Vol. 10, No. 1, 1969, hlm. 37.

92. Jumlah penduduk Singapura dari tahun 1823-1829 adalah seperti berikut:

\begin{tabular}{crcc}
\hline Tahun & Lelaki & Wanita & Jumlah \\
\hline 1823 & $\cdot$ & - & 10,683 \\
1824 & 8,620 & 3,231 & 11,851 \\
1825 & 9,147 & 3,708 & 12,855 \\
1826 & 10,307 & 3,425 & 13,732 \\
1827 & 11,368 & 3,507 & 14,875 \\
1828 & 13,976 & 4,232 & 18,208 \\
1829 & 13,976 & 4,241 & 18,217 \\
\hline
\end{tabular}

93. In spite of the severe measure adopted by the Dutch to prevent their subjects form sailing for Singapore and the threat pased by pinates infesting the waters of the Malacca Trends...", hlm.37).

94. SFR. Vol. 50, ff. $42-43$

95. The advantage of our factory at Singapore on its present footing cannot pertiaps be ment it was no soower establisheed as a fret withstanding the opposition of the Dutch governinto by the Dutch merchant at Batavia, and than specwlations were immediately entered proceed to Singapore for the purpase of and several ships are already engaged by them to import withowt the charge of dowble which Indian goads, which they are thess enabled to Batavia in British bottoms. The praduce the article wowld be liable to if imported from Singapone on equally 
Kemuncak peristiwa yang menguatkan hujah bahawa cita-cita Raffleslah yang menjadi faktor terpenting yang mendorong kepada dasar perdagangan bebas dan pelabuhan bebas dapat diperhatikan melalui cara bagaimana Raffles menguasai Singapura. Penguasaannya dibuat atas budi bicaranya sendiri.96 Kes ini mengukuhkan hujah bahawa perkembangan dasar perdagangan bebas dan pelabuhan bebas di Negeri-negeri Selat adalah realisasi impian Raffles di Timur. ${ }^{9 n}$

\section{UNTUK MENGAWAL KEGIATAN BELANDA DI KEPULAUAN MELAYU LEBIH-LEBIH LAGI SETELAH MEREKA KEMBALI BERKUASA MULAI TAHUN 1816}

Tindakan Raffles memajukan dasar perdagangan bebas juga bertujuan untuk mengawal kegiatan Belanda dan kuasa-kuasa asing lain di Kepulauan Melayu. ${ }^{98}$

favourable terms, thus the double duties exacted from foreign vessels at Batavia and Cal. cutta are naturally evaded to the manifest advantage of the commerce of both countries" (Surat Raffles kepada Setiausaha Syarikat Hinda Timur Inggeris di London pada 28 Disember, 1819, SFR, Vol. 50, ff. 42-43).

96. Hal ini terbukti dari surat balasan Gabenor Jeneral India kepada permintaan Raffles untuk menduduki Singapura. Dalam jawapannya dinyatakan penguasaan tersebut adalah atas kebijaksanaannya sendiri (Raffles) dan Syarikat Hindia Timur Inggeris tidak akan membiayai penguasaannya. If you wish to found a settlement at Singapore you may do so. The East India Company will not stop you. But it will not provide the expenses of the initial settlement. These must be borme jointly by you and Colonel Farquhar" (A.H. Hill. The Founding of Singapore Described by Munshi Abdullah" (translated). 150th Anniversary of the Founding of Singapore, JMBRAS, Vol. 42, Pt. 1, 1973. hlm. 94). Rujuk juga SSR (IOL), Vol. 10, f. 79.

97. Rumusan Kolonel William Farquhar, Residen Singapura yang pertama (1819-1823), tentang Raffles adalah kesimpulan yang paling tepat menggambarkan peranan Raffles dalam perkembangan Singapura. Menurutnya, Singapore had been founded at his (Raf Ales) own suggestion and matured under his personal management" (C. Clair. Sir Stamford Raffles, Fownder of Singapore, London, Bruice \& Gawthorn Ld., 1963. him. 92). Hal ini tidak menghairankan kerana apabila Kolonel Farquhar dilantik sebagai Residen pertama Singapura, Raffles telah mengarahkan supaya pelabuhan Singapura dikecualikan daripada cukai. "It is not mecessary at present to swbject the trade of the port to any dwties; it is yet inconsiderable, and it wowld be impolitic to incur the nish of obstrncting is advancement by any measure of this nature" (SSR (SNL), L10, f.6).

98. "Notes Illustrative of The Life and Services of Sir Stamford Raffles", JIA 1855, hlm. 310. Untuk lebih lanjut tentang kegiatan Belanda di Kepulauan Melayu rujuk J. Bastin, 
Dasar ini amat perlu lebih-lebih lagi setelah penempatan Belanda yang dikuasai sewaktu perang Napoleon dikembalikan ${ }^{99}$ Belanda kini kembali menguatkuasakan dasar monopoli. ${ }^{100}$ Paling membimbangkan adalah tindakan Belanda memaksa Raja-raja tempatan supaya tidak memeterai perjanjian perdagangan dengan British. ${ }^{101}$

... it is generally stipulated in their treaties, that the native power acknowledges the Dutch govermment as a feudal Superior, and engages not to enter into relations by treaty with other foreign powers; not to permit the residence of foreigners without permission of the Dutch East India Government; to receive a Dutch Resident, and to send a deputation or Embassy

Statement of The Services of Sir Stamford Raffles, 1978; I.H. Burkill, (ed)., "William Jack's Letters to Nathaniel Wallich, 1819-1821", JSBRAS, Vol. 73, 1916, hlm. 168-169; M.S. Carreon-Bunag, "The Founding of Singapore 1819", AST, Vol. 4, 1976; "Concerning Colonel Farquhar Going to Look for a place to Establish a Settlement", JLA 1852, hlm. 586-587. Khusus tentang aktiviti Belanda di Melaka setelah mereka kembali berkuasa rujuk A.H. Hill, "The Hikayat Abdullah", JMBRAS, Vol. 28, Pt. 3,1955, hlm. 132-137. 99. (SFR, Vol. 50, ff. 6-7). "Sir Stamford Raffles, in founding Singapore was impelled by a desire to protect the trade in the Archipelago, particularly in the face of mownting Dutch threat, following the repossession of Dutch passessions held briefly by the British from 1811-1816" (M.S. Carreon-Bunag, "The Founding of Singapore 1819", AST, Vol. 4, 1976, hlm. 532).

100. The Dutch are at their old work in the Indian Archipelago. They obliged all the native vessels to carny Dutch flags and Dutch peppers. They are taking passession of all the sorts in Borneo, Sumatra and etc for as to form the same system of arbitrany axclusion they did before they left the cowntry..." (PWIG, 12 Jun, 1819). Paling menarik ialah kenyataan Raffles kepada Colonel Addenbrooke yang bertarikh 10 Jun. 1819. Menurutnya Belanda telah meluaskan supremasi mereka ke seluruh Borneo dan Sumatera dan telah menafikan hubungan dengan negeri -negeri lain di Kepulauan Melayu. Menurutnya lagi, :.. whew I made my reapperance in these seas they (Dutch) had actwally hardly left ws an inch of grownd to stand mpon. Even owr rights to the spot on which I write this, though yestenday a wildermess and withowt inhabitants, is dispwted; and, in retwrn for owr wmparalled generousity, we are left almost withowt a nesting place in the Archipelago" (Raffles, "The Founding of Singapore", hlm. 72). Rujuk juga (SFR, Vol. 47, ff. 625-629). Lebih lanjut tentang dasar restriksi Belanda di Melaka antara tahun 1818-1825 rujuk C.M. Tumbull, "Melaka under British Colonial Rule", dalam Sandhu, K.S. \& P. Wheatley, Melaka, Tho Transformation of a Malay Capizal, C 1400-1980. Vol. 1, Kuala Lumpur, Oxford University Press, hlm. 240-247.

101. PWIG, 16 Januari, 1822. 
from time to time to the Governor-General of Dutch India, to asssist in putting down piracy: and renounce the right to wreck. ${ }^{102}$

Pendek kata dasar Belanda di Kepulauan Melayu adalah bersifat untuk mementingkan diri sendiri. ${ }^{103}$ Belanda tidak mengambil peduli kebajikan pedagang-pedagang asing dan tempatan. ${ }^{104}$ Keadaan ini diperburukkan lagi oleh usaha-usaha Belanda untuk menguatkuasakan pengaruh mereka di beberapa buah penempatan di Tanah Melayu. Kegiatan Belanda di Kepulauan Melayu yang giat dikatakan telah meluas meliputi seluruh Kepulauan Melayu. Keadaan ini telah memaksa Raffles mempengaruhi pemerintah Palembang supaya menyerang dan memusnahkan kubu Belanda di situ.

... you must throw out and destroy (buang habiskan sekali-kali) all the Dutch as well their Resident, and those who reside in Palembang under Dutch rule. In future allow no (Dutchmen) to reside or enter. Dutch residents can do no good. No Dutchmen should be allowed to enter the country of Palembang nor any other white people except the British. Should the British desire to have a trading place(loji) they should be allowed to do so on conditions to be determined later. ${ }^{105}$

Tindakan Raffles ini dengan jelas memperlihatkan betapa seriusnya beliau dalam membendung kegiatan Belanda di Kepulauan Melayu. Hal ini telah dilahirkan sendiri oleh Raffles dalam suratnya kepada pengarah Syarikat Hindia Timur Inggeris pada 10 April, 1818. ${ }^{106}$ Kebimbangan Raffles memperkukuhkan

102. Correspondence Respecting The Policy of The Netherlands Goverment in The Easterm Seas as Affecting British Commerce 1824, hlm. 78.

103. The Dutch, solely attentive to their own commercial interests, have in their intercource with the regions imvariably adhered to a more cold blooded, illiberal and wngenorows policy, than has ever been exhibited towands any cowntry... (Sophia Raffles, Memoir of the Life..., hlm. 75). Lebih lanjut tentang dasar restriksi Belanda rujuk $R C$, Vol. 1, hlm. 97, 101-106; Vol. 2, hlm. 1-21.

104. RC, Vol. 8, hlm. 58-59.

105. C.E. Wurtzburg, "Raffles and The Massacre at Palembang", JMBRAS, Vol. 22, Pt. 1. 1949, hlm. 42.

106. The policy and determination of the Dwich awthorities at Batavaia to aclude the British from all participation in the trade of Eastem Anchipelago and to secwer the comAlote command of the entrances into the China seas, has already evinced, istelf in the measwres they are presswring in the Southern Provinces of Swmatra ${ }^{\circ}$ (RC, Vol. 1, hlm. 217). 
keperluan mendapatkan sebuah penempatan di Timur untuk membendung kegiatan Belanda. ${ }^{107} \mathrm{Di}$ samping kuasa Belanda, kehadiran kuasa-kuasa asing lain seperti Amerika, ${ }^{108}$ Perancis ${ }^{109}$ dan Rusia juga turut membimbangkan Rafffles. Raffles berpendapat bahawa dengan menubuhkan pelabuhan bebas akan menyekat kuasa-kuasa asing seperti Rusia dan Amerika daripada bertapak di negeri-negeri berdekatan dengan Singapura.

The maintenance of a free port at Singapore, moreover would deter other European nations, especially France, Russia and America, from settling on the neighbouring coasts, for our continental possessions will enable us to do that (i.e. maintain a free port), without considering it as a loss, which no other nation could do except at a dead loss, in consequence of the greater distance of their power. 110

Kebimbangan ini menjadi lebih nyata bila dikatakan beliau pernah mendapat maklumat bahawa Belanda menyokong Rusia dalam usaha menguasai Kepulauan Pasifik.

107. Tindakan Raffles mengisytiharkan Bangkahulu di Jawa sebagai pelabuhan bebas pada tahun 1818 adalah bertujuan untuk mengawal kegiatan Belanda ("Notes Illustrative of The Life and Services of Sir Stamford Raffles", JLA, 1855, hlm. 312; Hahn, Raffles of Singapore, $\mathrm{hlm}$. 81). Di sebalik tujuan membendung kegiatan pihak Belanda, dasar perdagangan bebas juga bertujuan untuk memaksa pihak Belanda supaya menerima dasar-dasar liberal. Swch an establishment would maintain a successful rivalny with the Dutch, who wowld be obliged vither to adopt a liberal system of free trade or be compelled to see the trade collected under the British flag: in either case our object would be answered"(H.R.C. Wright, East Indian Economic Problems of the Age of Comwallis and Raffies, London. Luzac \& Co. Ltd., 1961, hlm. 352; Donald Moore dan Joanna Moore, The First 150 Years of Singapore, Singapore, Donald Moore Press Ltd., 1969, hlm. 51).

108. Aktiviti kuasa Amerika di Aceh dihalkan dengan mendalam dalam surat-surat Raffles. Pada tahun 1818 kapal-kapal Amerika dikatakan menerima kargo di Aceh (RC, (PWIG, 15, September 1821). Amerika rujuk Cook, Sir Thomas Stam lanjut tentang kebimbangan aktiviti pedagang JLA, Vol. 7, 1853, hlm. 109. Kegiatan Perancis terlihat di Cochinc, Memoir of the Lite..., hlm. 84-86).

11-14). Kapal-kapal Perancis dikatakan telin-China, Pegu dan Arakan (RC, Vol. 8, hlm. pada 13 Julai, 1811 (PWTG, 13 Julai, 1811). 110. (BSP, 1820, Vol ?, $P$

Singpore...: hlm. 179). 
He had heard that Holland was supporting Russia in it's attempts to secure Pacific Islands, and felt that this increased the dangers to Britain in the East. He became even more determined to check the extension of Dutch infuence in any form. ${ }^{111}$

Jelaslah bahawa kebimbangan ancaman Belanda dan kuasa-kuasa asing lain turut menjadi salah satu sebab Raffles menganjurkan dasar perdagangan bebas dan pelabuhan bebas di Kepulauan Melayu.

\section{UNTUK MEMENUHI KEHENDAK PEDAGANG PERSENDIRIAN (PRIVATE TRADERS) LEBIH-LEBIH LAGI SETELAH TAMAT MONOPOLI PERDAGANGAN SYARIKAT HINDIA TIMUR INGGERIS DENGAN INDIA}

Keperluan Raffles mengadakan pelabuhan bebas dan dasar perdagangan bebas juga bertujuan untuk menjaga kepentingan pedagang persendirian lebih-lebih lagi setelah monopoli perdagangan Syarikat Hindia Timur Inggeris dengan India dimansuhkan pada tahun $1813 .{ }^{112}$ Perkembangan ini menyebabkan Singapura mula menjadi pusat untuk pedagang-pedagang persendirian mengumpul barangan Kepulauan Melayu untuk dipasarkan di China. Untuk membantu memesatkan perdagangan ini, pihak Inggeris telah menggalakkan penubuhan beberapa buah firma perdagangan. Firma Alexander Johnston muncul sebagai firma pertama pada tahun 1820 dan berurusan dalam mengirimkan barangan dari Canton ke Eropah melalui Singapura dan menerima barangan seperti timah dan hasil-hasil Selat dari Kepulauan Melayu untuk diagihkan di China. Selepas Firma Johnston, muncul pula beberapa buah firma hain, antaranya Alexander Guthrie, 1821; Syme and Co., 1823; Pattersons, Simons and Co., 1823 dan Boustead and Co., 1830.13 Kemunculan firmafirma ini telah memesatkan lagi perdagangan Singapura dengan Kepulauan Melayu dan negeri China. Pada waktu ini, monopoli perdagangan England dan China tetap dikuasai oleh Syarikat Hindia Timur Inggeris, sedangkan perdagangan

111. J.S. Tay, "The Attempts of Raffles to Establish A British Base in South East Asia", SEEAH, Vol. 1, No. 2, 1960, hlm. 4.

$112 . S C, 30$ Julai, 1829.

113. KG.P. Tregonning, The Britist in Malase: The Fins Font Years, 1786-1826, blatm. 154. 
England dengan China telah menjadi penting disebabkan teh, tetapi imbangan perdagangan tidak menyebelahi England. Oleh itu Singapura mesti dijadikan pelabuhan bebas untuk menarik pedagang-pedagang tempatan ke sini. ${ }^{14}$

Kepentingan perdagangan China ini telah mendorong Raffles berikhtiar untuk menguasai Selat Melaka dan Selat Sunda, dua selat yang bakal membawa kemajuan dari segi perdagangan kepada Singapura. Raffles melihat koloni sebagai mempunyai dua peranan; pertama, sebagai penyumbang pendapatan (colonies of revenue) dan kedua sebagai pemaju perdagangan (colonies of trade). Dalam konteks ini Singapura dan Pulau Pinang berperanan sebagai koloni perdagangan (colony of trade), manakala Bangkahulu, Jawa, Palembang dan Negeri-negeri Melayu sebagai koloni pendapatan (colony of revenue). ${ }^{115}$

Singapura diharapkan dapat memainkan peranan sebagai pusat pertemuan di antara pedagang-pedagang persendirian England dan jongkong-jongkong China. Melalui pertemuan ini diharapkan barangan England dapat diperkenalkan di China. Ini adalah kerana pedagang-pedagang China mempunyai lebih banyak kebebasan daripada bangsa-bangsa asing di pelabuhan mereka. ${ }^{116} \mathrm{Di}$ samping itu Singapura juga dapat berfungsi sebagai pusat mengumpul hasil Kepulauan Melayu. Berhubung dengan peranan dan faedah yang bakal diperolehi oleh England sebagai orang tengah telah dibayangkan oleh ahli ekonomi bernama Sombart. Menurutnya, walaupun koloni tidak menghasilkan sebarang hasil yang menguntungkan tetapi mampu untuk mengumpul hasil kekayaan dari kawasan sekitarnya. ${ }^{117}$

Di samping memenuhi kehendak pedagang persendirian, tindakan Raffles juga bertujuan untuk memenuhi matlamat politiknya sendiri. Sewaktu Raffles berada di England beliau menjadi pejuang perdagangan bebas dan penyokong

\footnotetext{
114. Bastin, Statement of the Services of Sir Stanvfond Rafiles, hlm. 54.

115. Wright, East Indian Ecomomic Problews..., htm. 352.

117. Wright, East Indian Ecomomic Problemse.., hlm. 352.

to Nineteenth Centuries". "Foreign Trade of Russia and Britain with Asia in the Seventeenth to Nineteenth Centuries". MAS, Vol. 21, No. 4, 1987, hlm. 633 .
} 
kuat golongan pengusaha. ${ }^{11 x}$ Sewaktu Raffles berangkat ke Bangkahulu, beliau sebenamya mahu kembali ke England dalam masa lima tahun dan selepasnya mahu menjadi ahli Parlimen dan menyokong golongan aristokrat. Kaffles berpendapat satu-satunya cara untuk mencapai objektif ini ialah dengan bekerja dengan golongan yang menyokong diwujudkan perdagangan bebas.

Hal ini tidak menghairankan kerana golongan pedagang persendirian sendiri telah berulangkali mendesak supaya Singapura dimajukan sebagai pelabuhan bebas. ${ }^{119}$ Pedagang-pedagang ini percaya tindakan ini dapat mengalahkan Belanda dan memaksa mereka tunduk kepada kehendak England. Dalam surat mereka kepada Lord Viscount Castlereagh yang bertarikh 21 September, 1821 pedagang-pedagang persendirian ini telah mengajukan tujuh sebab mengapa Singapura harus dimajukan sebagai pelabuhan bebas. ${ }^{120}$

118. -... life at home as a distinguished savant, colonial expert and porponent of free trade, the spokeman in effect, of the manufacturing and commercial interests which resented the restrictions placed on their access to eastem markets by East India Company's privileges and by the British Govermment's support of the Dutch in the East. When Raffles left for Bencoolen it was with the firm intention of returming within five years after which he hoped to enter Parliament with the support of his aristocratic patrons. Meanwhile it was desirable that he should establish his reputation with some master-stroke on behalf of the free traders" (C.H. Wake, "Raffles and The Rajahs: The Founding of Singpore in Malaya and British Colonial History", JMBRAS, Vol. 48, Pt. 1, 1975, hlm. 53). Hal ini juga disokong oleh Andrew Clarke dalam artikelnya berjudul "Sir Stamford Raffles and The Malay States" Menurutnya, "Raffles was a Free Trader before the phrase was known in party politics at home. While the East India Company clung to it's mowopolies, Raffles, it's servant, made every port within its jurisdiction a free pont, and with the ome exception of opium, allowed every anticle to be exported or imported under all friendly flags at a customs rate of five percent" (Raffles Printed Sources, Vol. 3, hlm. 5).

119. Hal ini terlihat daripada surat yang diajukan oleh seorang Private Trader Timur pada 15 September, 1821. Menurutnya, :... it is our policy to make our stations to he eastwand free ports: subject to no duties, to no restrictions; encumbered with no collectors of customs; and consequently exempt from all seizure of the goods of the wrwany, and what is of yet more importance, from all smuggling." "At Singapore this system has been introduced The trader comes and goes, buss and sells, unmodelled by fiscal negulations;" Beliau menambah, :.... if it (Free porta) were extended to one or two more of our stations in the Eastem Isles, it wowld either force them (Dwtch) to throw open their ports to our traders, or to fit still and see all the eastem trade find its way to owrs" (PWTG, 15 September, 1821).

120. PWIG, 29 September, 1821. 
Selaras dengan kehendak golongan pengusaha, Raffles telah mengikhtiarkan pembentukan sebuah perlembagaan di Singapura yang bakal memberi kebebasan kepada pedagang-pedagang persendirian England. ${ }^{121}$ Keadaan ini juga tidak menghairankan kerana pedagang-pedagang Negeri Selat juga mempunyai pengaruh yang kuat di parlimen England. Mereka sering melobi supaya perdagangan di Timur dibuka luas kepada pedagang-pedagang persendirian. ${ }^{122}$ Perjuangan Raffles menjadi realiti apabila pada 1 Januari, 1823 Singapura secara rasmi diisytiharkan sebagai pelabuhan bebas. ${ }^{123}$

Dalam keadaan ini tindakan Raffles memenuhi kehendak golongan pengusaha dan pedagang persendirian juga bererti memenuhi cita-citanya sendiri.

\section{MEMBIAYAI EKONOMI ENGLAND YANG TERJEJAS AKIBAT PEPERANGAN}

Keperluan Raffles menganjurkan dasar perdagangan dan pelabuhan bebas juga bertolak daripada kesedaran untuk membiayai ekonomi negaranya yang terjejas akibat peperangan.

Sepanjang abad ke-18 dan awal abad ke-19 England telah terseret dalam beberapa siri peperangan dan telah meninggalkan kesan yang buruk kepada exonominya. England telah terlibat dalam perang Kemerdekaan Amerika pada tchun 1776, peperangan dengan Perancis (1793-1815) dan peperangan dengan Amerika (1812-1815). Ketiga-ketiga peperangan ini telah melibatkan kos yang tinggi. Perang Kemerdekaan Amerika telah melibatkan perbelanjaan sebanyak

\footnotetext{
121. He was detenwined to comswmate his labowrs in the east by giving Singapone a Constivtion' which would provide for its continuance a free port serving the interests of Britich Arivate traders" (Wake, "Rafiles and the Rajahs...", hlm. 65).



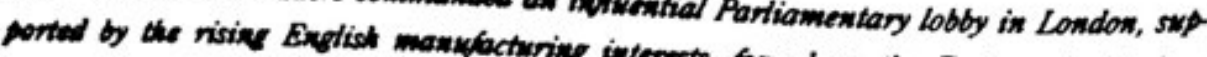
wes an important potential manth" (C.D. Cotenost, for whom the Eastern Archipelago rims of British Palitical Comtral, London. Oowan, Nincternth Centwry Malaya, The On123. SSASNI), 117, ff 236-241.
} 
100 juta pound sterling, ${ }^{124}$ peperangan dengan Perancis, 234 ribu juta pound sterling dan peperangan Amerika pula 834 ribu juta pound sterling. ${ }^{125}$

Dalam keadaan ini perdagangan bebas dan pelabuhan bebas adalah usaha untuk menguasai perdagangan di Timur bagi membiayai perbelanjaan perang England. Raffles sendiri pernah bertanya:

... for unless a monopoly of the Eastern commerce were insisted upon, how was England to maintain a war which is every year draining her of her best resources... . ar

Langkah memajukan Singapura sebagai pelabuhan bebas mendatangkan faedah kepada India dan England. Pedagang-pedagang persendirian Inggeris di India kini dapat menjual barangan mereka di Singapura untuk diniagakan di China dan Kepulauan Melayu. Di pihak England pula, barangan Kepulauan Melayu yang bebas cukai di Singapura bila dibawa ke England akan tetap dicukai. Dari segi ini, status pelabuhan bebas Singapura memang mendatangkan faedah yang besar kepada England. ${ }^{127} \mathrm{Hal}$ ini terbukti daripada nilai eksport Singapura ke Britain antara tahun 1823-1834. Eksportnya meningkat dari 1,147,944 dolar Sepanyol antara tahun (1823-24) kepada 3,428,132 pada tahun $(1833-34) .128$

Berkaitan dengan faktor ini, kemerosotan Pulau Pinang juga turut mempercepatkan tindakan Raffles menganjurkan dasar perdagangan bebas dan pelabuhan bebas di Kepulauan Melayu. Pulau Pinang pada peringkat awal telah menikmati perdagangan yang pesat dengan negeri-negeri berdekatan Semenanjung Tanah Melayu seperti utara Sumatera, Burma dan Siam. Walau bagaimanapun, kepesatan perdagangan ini tidaklah lama, perdagangannya mula

124. H.L Peacock, British Histony, 1714 - Aresent Day, London, Heinemann Educational Books, 1979, hlm. 94.

125. P. Lane, Swccess in British Histong 1750 - 1941, Norwich Fletchers and Sons Ltd. 1978, hlm. 74.

126. Bastin, "Raffles and British Policy in the Indian Archipelago 1811-1816", JMBRAS,

1954, hlm. 91.

127. SSR (SNL), Series AA7, 1. 216; SSR (SNL), A 13, fi. 1920.

128. Wong Lin Ken, The Trade of Singapore 1819.1869, htm. 
mei osot menjelang tahun 1811 apabila Stamford Raffles menguasai Jawa pada tahun 1811 dan mengamalkan dasar liberal. Dasar ini menyebabkan kegiatan penyeludupan bijih timah yang sebelumnya dijalankan dengan giat dari penempatan seperti Bangka ke Pulau Pinang, terjejas. Kemerosotannya juga disebabkan oleh kegiatan perlanunan yang berleluasa di Selat Melaka dan kawalan perkapalan Belanda di Selat Melaka pada penghujung abad ke-18. ${ }^{129}$ Di samping itu perdagangan yang dahulunya tertumpu di Pulau Pinang untuk mengelakkan duti tinggi pihak Belanda kini beralih ke Betawi. ${ }^{130}$

Dalam keadaan ini wajarlah sebuah pelabuhan baru yang mengamalkan dasar perdagangan bebas diwujudkan untuk mengambilalih kedudukan Pulau Pinang dan perdagangan yang di monopoli di kawasan-kawasan sekitarnya.

Berdasarkan perbincangan dapat diperhatikan betapa Francis Light dan Stamford Raffles telah menyumbang kepada perluasan dasar imperialisme British di Negeri-negeri Selat antara 1786-1826. Walaupun tindakan mereka menguasai kedua pelabuhan ini pada peringkat awal mendapat tentangan daripada kerajaan India tetapi setelah menyaksikan perkembangan pesat pelabuhan berkenaan, Britian telah menyambut baik langkah memajukan penempatan-penempatan ini.

129. C.D. Cowan, "Governer Bannerman and The Penang Tin Scheme 1818-1819", JMBRAS, Vol. 23, Pt. 1, 1950, hlm. 55.

130. Trade which used to go to Penang to ascape the light duties of the Dutch awthorit ties was drawn back to Batavia. The merchants of Calcutta and Madras could supply the Batavian market with much more porfit than those of Powavs" (Cown, "Early Penang and The Rise of Singapore...", hlm. 6-7). Lebih lanjut rujuk juga Courtenay, A Geogro Ahy of Trade... : hlm. 68: Margaret Lee, "Trade and Shipping in Earty Penang". MIH. Vol. 21. No. 2, 1978, hlm. 22. 